\title{
Rasionalisasi Ideologi Sunda Wiwitan (Kabuyutan): Penyatuan Diri Urang Sunda Kepada Gunung Sebagai Lambang Semesta (Kosmis)
}

\section{Richadiana Kartakusuma}

Keywords: culture, history, Sundanese, ethnoarchaeology, west java

\section{How to Cite:}

Kartakusuma, R. (2006). Rasionalisasi Ideologi Sunda Wiwitan (Kabuyutan): Penyatuan Diri Urang Sunda Kepada Gunung Sebagai Lambang Semesta (Kosmis). Berkala Arkeologi, 26(1), 86-94. https:// doi.org/10.30883/jba.v26i1.927

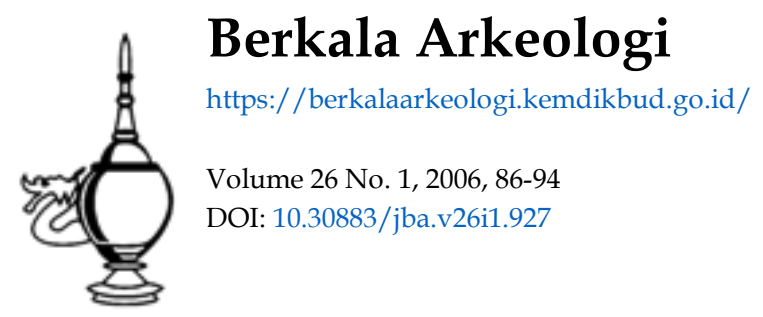

\section{c) (i) (2)}

This work is licensed under a Creative Commons Attribution-NonCommercial-ShareAlike 4.0 International License. 


\section{RASIONALISASI IDEOLOGI SUNDA WIWITAN (KABUYUTAN): PENYATUAN DIRI URANG SUNDA KEPADA GUNUNG SEBAGAI LAMBANG SEMESTA(KOSMIS)}

Richadiana Kadarisman Kartakusuma

\section{Permasalahan}

Tulisan menyajikan sejarah kebudayaan Sunda secara holistik agar dimengerti lebih mendalam, bukan bertahan pada konsep-konsep abstrak namun lebih bersifat operasional. Dengan tanpa menutup mata terhadap kekurangan dan kelemahan yang ada, uraian tentang kebudayaan Sunda berpijak pada kenyataan-kenyataan objektif, mudah dipahami dengan kerangka pikir sistematis sehingga gambaran dan makna kebudayaan Sunda tampak jelas.

Berbicara kabuyutan hubungannya dengan Sunda Wiwitan adalah membahas kebudayaan Urang Sunda, konsekwensinya dihadapkan pelbagai permasalahan hubungan masa lalu ke masa kini. Khususnya pengalaman peristiwa kehidupan Urang Sunda di masa lalu dengan masa sekarang yang dalam khasanah sejarah Indonesia dirasakan sangat kurang. Sebenarnya, persoalan diawali ketika para sarjana kolonial menyatakan bahwa di Pasundan "tidak atau jarang ada candi (bangunan suci Hindu-Budha)", karena tampak fisik sejumlah besar sisa aktivitas budaya yang ditemukan di Tatar Sunda lebih menampilkan bangunan-bangunan bercorak (khas) tradisi megalitik. Mereka menganggap bahwa warisan budaya karya monumental tersebut berasal dari periode prasejarah murni. Kesannya, Urang Sunda tidak memiliki candi dari periode Klasik.

Bangunan suci "candi" yang dimengerti dan diacu sebagian besar masyarakat kita selama ini adalah andil dan hasil persepsi sarjana kolonial "bangunan megah dan anggun seperti di daerah-daerah lain di Indonesia". Karena ketidakpahaman makna (meaning) kebudayaan Urang Sunda. Ironisnya asumsi sarjana kolonial itu diadaptasi banyak kalangan ilmuwan Indonesia dengan memberi pengertian universal terhadap yang disebut "candi' untuk menilai segala aktivitas budaya 
khususnya bangunan keagamaan. Pendapat yang melahirkan kontradiksi lebih parah bahwa jikalau dalam suatu sisa aktivitas budaya di Tatar Pasundan khususnya yang telah sangat jelas menampakkan suatu bangunan teras berundak kerap mengindikasikan corak tradisi megalitik terdapat arca yang "diduga" Hindu-Budha, serta merta diasumsi bangunan suci Hindu-Budha. Padahal arca itu satu-satunya lepas dari matrixnya, nampak diletakkan begitu saja di tempat itu (tidak intax). ${ }^{1}$

Agus Aris Munandar (1992) menganalogikan bangunan-bangunan kabuyrtan dengan punden berundak yang banyak tersebar di Jawa Timur (Gunung Penanggungan). Bahwa kabuyutan dari masa kerajaan Sunda (Jawa Barat) tidak berbeda dengan di Jawa Timur sekitar abad ke13-14 M (Majhapahit). Lingkungan situs dan pengelolanya disebut palelemahan dan kawikwan adalah juga mandala kadewagurwan, karena kawikwan berasal dari kata dasar wiku $=$ resi ${ }=$ pengelola padepokan, disebut mandala . Karena itu kabuyutan Sunda dan kabuyutan di masa Majhapahit tiada berbeda yakni pusat upacara keagamaan dengan unsur utama pantheon Hindu (-Budha), ataupun tokoh-tokoh yang diperdewakan (diwujudkan sebagai arca).

Berbagai artikel Munandar tentang bangunan keagamaan Sunda merupakan hasil analisis sangat cermat yang dirangkai runut disertai ragam data mulai dari unsur terkecil (pelaku, objek, waktu, ruang) hingga tingkat peristiwa (episode) menjadi untaian pisode chains, jalinan struktur-sosial budaya saling berhubungan dan berhasil menuntun setiap pemerhati atas pernyataannya tentang "kabuyutan adalah mandala kadewagurwan para resi". ${ }^{2}$ Lebih dari itu, Ayatrohaedi pernah

\footnotetext{
${ }^{1}$ Ketika penulis melakukan penelitian di Ciamis (Laporan Penelitian Arkologi di Kabupaten Ciamis, Jawa Barat Tahun 2001-2003) berkali-kali menyaksikan gejala yang menyesatkan bahwa yang konon disebut arca Ganesa di Situs Karangkamulyan (Batu Pangcalikan) sernata-mata penamaan oleh penduduk setempat, kenyataannya tidak lebih dari bongkah batu yang secara analisis gelologis telah mengalami pelapukan oleh cuaca. Ciri-ciri atribut yang dimiliki oleh arca Ganesa tidak ada samasekali. Begitupun Batu Pangcalikan itu sendiri adalah sisa umpak sebuah bangunan yang berukuran cukup besar terbuat dari batu pasir yang diletakkan terbalik dan diatur sedemikian rupa sehingga nyaman untuk tempat duduk. Tempat ini memang dicipta sebagai tempat semedi oleh yang mengaku mencipta tempat ini.

${ }^{2}$ Pendapat Agus Aris Munandar ini selanjutnya diperkuat oleh Eti Saringendiyanti (1993) dalam tesisnya berjudul Penempatan Situs Upacara Pada Masa Hindu Buda, Sebuah Kajian Lingkungan Fisik Kabuyutan di Jawa Barat, Tesis-S2 Arkeologi, Program Studi Arkeologi Bidang Ilmu Pengetahuan

Budaya, Program Pasca Sarjana Universitas Indonesia.
} 
menyimpulkan bangunan suci Urang Sunda berkembang sebagai perpaduan antara kepercayaan pribumi dan unsur Hindu-Buda aliran Tantrayana. Bahkan Dodong Djiwapraja (1991) lebih menegaskan bahwa Sunda Wiwitan telah dirasuki Hindu-Budha seuntuhnya. ${ }^{3}$

Peristiwa yang dikemukakan hanya beberapa contoh saja dari sekian banyak pendapat para sarjana yang pernah menyatakan bahwa masa Hindu Budha yang sebenarnya merujuk istilah untuk menandai masa klasik digeneralisasi sebagai inovasi Hindu-Budha dan segenap perangkat keagamaanya. Padahal kenyataan tidak demikian. Realitas itu ditopang fakta dari sejumlah sumber tertulis Tatar Sunda, tiak satupun menyebut candi tetapi Kabuyutan. ${ }^{4}$ Sesuai pernyataan Soekarto K. Atmodjo (1986:53): ${ }^{5}$

"sensus divinus dalam bentuk religio atau relevatio naturalis yang tumbuh di kalangan masyarakat, baik yang masih mendekati asli maupun yang telah berkembang setelah kontak dengan agama Hindu-Buda jangan ditentang (dikecam), melainkan biarlah berkembang sampai sotuasi dan kondisi (desa - kala-patra) memungkinkan untuk menerima pembaharuan pengetahuan (teknologi, wahyu Tuhan), sebab apabila ditentang akan menimbulkan gejala atau kekosongan patologis, yaitu bahaya pengasingan diri dan kehilangan identitas (kepribadian)"

Namun Daud Aris Tanudirjo (1984: 24) menuturkan "memang benar kesenian dan bahasa diakui memberi kesan dipengaruhi Hindu-Buda, kesan itu sebenarnya

\footnotetext{
${ }^{3}$ Dodong Djiwapradja (1991), Suatu Tinjauan Terhadap Etika Dan Nilai Budaya Pada Masa Pakuan Pajajaran, Proceeding Seminar Nasional Sastra Dan Sejarah Pakuan Pajajaran, Bogor, 11-13 Nopember 1991.

${ }^{4}$ Boechari dalam Candi dan Lingkungannya (PIA, 1980:331) menyatakan bahwa pola pemukiman desadesa di Jawa masa lalu diatur menurut konsep mancapat (panyatur desa) dan mancalima (pangasta desa), suatu desa dikelilingi empat desa atau kelipatannya sesuai arah penjuru mata angin. Ada juga desa yang dikelilingi tiga, lima, enam atau kelipatannya, tetapi jumlah-jumlah itu tidak dijumpai dalam prasasti dan bagaimana polanya belum diketahui. Andai saja kala itu Boechari berkenan meluangkan sedikit waktunya menengok ke arah Sunda (cerita tutur atau tradisi lisan misalnya), tentu akan menemukan jawabannya. Pola kosmis masyarakat Sunda merapkan konsep triumvirat yakni Thu Tangtu di Bumi (konsep tiga) yang tidak akan ditemukan di dalam prasasti-prasasti Jawa.Karena polanya mengacu Hulu-Hilir arus sungai dengan pusat Hulu (gunung) sebagai sumber (upstream-downstream). Jawa Tengah dan Jawa Timur memang berada dalam kesatuan mandala (kosmis), Sunda memiliki mandala yang berbeda dengan mandala Jawa Tengah dan Jawa Timur.
} 
hanya sebatas kulit saja". Ia melandaskan asumsinya atas fakta yang disampaikan W. F. Stutterheim saat meneliti epic Ramayana Indonesia, betapa dominannya unsur-unsur cerita rakyat di dalamnya. Sistem permakaman di bukit atau bangunan berundak mencerminkan konsep asli. Konsep keagamaan pun terjadi sinkretisme budaya asli dan Islam. Unsur Islam yang muncul hanya pembungkus kebudayaan asli. ${ }^{6}$ Begitupun I Gusti Ngurah Anom (1996:24) tatkala menemani seorang Rabindranath Tagore di Indonesia (1927), menyatakan "I see India everywhere, but I do not recognize it". ${ }^{7}$

Nyatalah bahwa tatkala unsur pengaruh asing datang, tidak ditelan mentah-mentah tapi sekedar diserap yang dianggap perlu untuk turut ambil bagian atas trend baru yang waktu itu tengah mengalami pamor dan berkembang di Asia sekedar memperkaya kebudayaannya. Kenyataannya bangsa Indonesia tetap berlandaskan kepada nilai budaya selektifitu. ${ }^{8}$ Kiranya pula generalisasi atas kabuyutan Sunda dan kabuyutan Jawa (Majhapahit) yang dilakukan para sarjana tidaklah salah.

Tanpa mengurangirasa hormat setinggi-tingginya atas jasa telaah para pendahulu itu adalah wajar bila pendapat itu dikatakan lebih besifat persepsi etik. ${ }^{9}$ Unsur pengaruh Hindu-Budha tidak membawa perubahan kebudayaan yang kualitatif (morphogenesis) tetapi hanya pada taraf kwantitatif (morphostatis). ${ }^{10}$ Mustahil rasanya jikalau kolonisasi atau Indianisasi dengan kesan bahwa bangsa Indonesia sejak dahulu hanya dipengaruhi bangsa lain memang sebaiknya dihapus saja. Sebab bangsa Indonesia adalah bangsa mandiri, dalam kenyataannya mampu berdiri sama tinggi dalam pergaulan internasional. Hal ini pun berkali-kali dibuktikan Noerhadi Magetsari (1986) dan Edi Sedyawati (1987) bahwa sikap bangsa seperti itu hanya terjadi bilamana suatu bangsa bermental kuat dengan dasar landasan pengetahuan

\footnotetext{
${ }^{5}$ M.M.Soekarto K.Atmodjo, Pengertian Local Genius dan Relevansinya dalam Modernisasi, dalam Ayatrohaedi (peny.,), Kepribadian Budaya Bangsa (Local Genius). Jakarta: Pustaka Jaya. 1986: 46-71.

${ }^{6}$ W.F.Stutterheim (1925), Die Rama-legenden und Rama-reliefs in Indonesien (The Rama-legends and Rama-reliefs in Indonesia), Munchen; De Stichter der Prambanan-tempels (The Builder of the Prambanan- temples) in Djawa, 1940:218-233.

${ }^{7}$ I G.N. Anom (1996), Keterpaduan Aspek Teknis Dan Aspek Keagamaan Dalam Pendirian Candi Periode (Studi Kasus Candi Utama Sewu). Disertasi. Yogyakarta: Universitas Gadjah Mada. Pada halaman 24: "proses masuknya kebudayaan India sampai dengan menghasilkan candi yang bercorak Indonesia dapat dikatakan sama dengan proses psikologis yang dialami seorang arsitek dalam perancangan suatu bangunan. Semua informasi diolah, diseleksi ber-dasarkan orientasi nilai dan pengalaman yang dimilikinya sehingga
} 
tinggi yang telah ada sejak awal.

\section{Konsepsi Kebudayaan Urang Sunda}

Menurut Koentjaraningrat (1986:80-90) wujud dan unsur setiap kebudayaan di dunia memiliki variabel universal. Dipastikan bahwa setiap benda budaya merupakan dayacipta manusia selalu telah dimaknai (individu) oleh si pencipta atau pembuatnya. Maka makna setiap artefak adalah mutlak kekayaan kebudayaan sesuai pengalaman bathin para pemangku budaya. ${ }^{11}$ Setiap artefak walaupun mungkin secara fisik terlihat "seperti sama atau mirip" tidaklah selalu harus dianggap sama atau dipersamakan melainkan ciri [karakter] sebagai bagian keunikan yang khas dirinya baik sebagai individu maupun masyarakat. Kabuyutan sebagai pusat upacara keagamaan Urang Sunda tidak hadir dan lahir sebagai sesuatu kebetulan tetapi sarat imaji proses pengalaman teramat panjang, mencakupi segi-segi kehidupan Urang Sunda. Secara garis besar bertumpu kepada 4 faktor poros fenomen budaya: ${ }^{12}$

1) Manusia (antrophos), secara individual adalah faktor sentral pelaku budaya. Bukan hanya sebagai subyek pendukung, juga pencipta dengan kekhasan yang membedakannya dengan individu lain, termasuk kemampuan (daya) kreativitas di dalam mengolah lingkungan alam menjadi lingkungan (kebudayaan) manusiawi 2) Ekosistem (oikos), universum kosmis merupakan tempat individu menjalankan proses pembudayaan. Ekosistem tidak sekedar sarana kelangsungan hidup, tetapi medan yang memungkinkan berjuang untuk hidup, menuangkan karyakaryanya (lebenswelt) menciptakan hubungan struktural manusia dan

menghasilkan suatu rancangan yang khas baik bentuk maupun keindahannya. Arsitektur sebagai suatu karya manusia untuk manusia, tidak dapat dinilai sebagai suatu seni bangun saja, tetapi harus selalu dalam konteks pernakainya. Suatu karya arsitektur baru dapat dinilai berhasil bila ia telah dapat berfungsi sebagaimana diharapkan".

${ }^{8}$ Franz Magnis-Suseno (1983), Etika Jawa (Sebuah Analisa Falsafi Tentang Kebijaksanaan Hidup Jawa), Jakarta, PT.Gramedia; Noerhadi Magetsari (1986), Local Genius dalam Kehidupan Beragama. dalam Ayatrohaedi (penyunting). Kepribadian Budaya Bangsa (Local Genius). Jakarta:Pustaka Jaya. Halaman 72-79; Edi Sedyawati (1987), Tarumanagara: Penafsiran Budaya, Diskusi Panel Menggali Kembali Sejarah Taruma-nagara.Jakarta, 12 September 1987. Cetakan lepas.

${ }^{9}$ Ronny Siswandi (1986), Pendekatan Emik dan Etik dalam Etnoarkeologi, makalah dalam Pertemuan Ilmiah Arkeologi (PIA) IV, Cipanas, 3-9 Maret. Sub Tema III: Konsepsi dan Metodologi. Departemen Pendidikan dan Kebudayaan, Pusat Penelitian Arkeologi Nasional.Halaman 249-263. Menurutnya emik adalah cara yang dilakukann peneliti tatkala hendak mencari dan menemukan perbedaan dari sisa aktivitas yang ter-dapat di dalam suatu himpunan (terdiri dari beberapa kelompok) masing-masing ditandai dengan 
lingkungannya

3) Teknologi (tekne) atau peralatan yang digunakan sebagai perpanjangan tangan untuk mengerjakan dunianya. Kemajuan teknik adalah penceminan perilaku yang dipahami sebagai perkembangan kebudayaan,

4) Komunitas (ethnos), terciptanya kebudayaan merupakan hasil interaksi di antara pribadi-pribadi yang tergabung sebagai masyarakat.

Dalam mengkaji fenomena kebudayaan Noerhadi Magetsari (1986) juga Daud Aris Tanudirjo (1994) pernah menawarkan metode gabungan etik-emik, suatu metode Arkeologi konteks atau interpretif guna memahami record masa lampau direalisasikan dengan menerapkan empatetik (emphatetic approach). Pendekatan tersebut dasarnya mengakui bahwa meski tindakan manusia dan budaya bendawi yang telah dihasilkan suatu budaya tertentu bersifat unik dan khusus dan memiliki unsur-unsur yang sama tetapi tidak berarti harus digeneralisi dengan penjelasan cross-cultural (silang budaya) dan diterapkan begitu saja. Namun harus dijelaskan dengan menempatkan diri si peneliti menjadi bagian budaya yang ditelitinya yang disebut metode Hermeneutik.

Di dalam lingkaran hermeneutik semua tuntutan arkeologi konteks seperti peran individu, pemahaman dalam konteks luas, dimana kekhususan sejarah tidak selalu harus te-rgantung pada dalil atau teori. Karena interpretasi tentang masa lalu tidak seharusnya menjadi interpretasi mandeg tapi merupakan interpretasi yang terus berkembang sampai pada titik yang tidak lagi dapat dipertanyakan dalam lingkaran pemikiran tiada terputus-putus. Dalam proses tersebut terjadi dialektika antara bagian keseluruhan (partwhole dialectic) untuk mencapai pengertian yang lebih benar. ${ }^{13}$ Artinya suatu fenomena (part) baru dapat dijelaskan jikalau peneliti menempatkan fenomena tersebut dalam keseluruhan konteksnya (whole),

sejumlah unsur pembeda. Jadi cara emik adalah analisis komponensial melalui pemilahan tip-tiap himpunan dari yang paling umum hingga yang paling spesifik hingga menuju landasannya yakni semantik.

${ }^{10}$ Morphogenetic dan morphostatic adalah tataran teori untuk meninjau terjadinya perubahan kebudayaan. Morpho=bentuk, dan genetic diartikan penciptaan; static merujuk pada arti mantap atau tetap (stabil). Kedua istilah ini diterapkan dalam suatu sistem seperti individu/kelompok manusia dimana selalu terjadi per-ubahan kecil, misalnya kelahiran dan kematian sehingga anggota kelompok berubah secara alami. Tetapi dari segi kebudayaan tidak terjadi perubahan karena adat-istiadat, bahasa, agama dan sebagainya itu selalu diwariskan secara turun temurun sehingga kebudayaan kerap disebut sesuatu yang super-organic yaitu kebudayaan merupakan bagian dari manusia yang terdiri dari bahan organik, tetapi tidak meninggal jika pembawa-pembawanya meninggal. 
sebaliknya, fenomena yang diteliti dapat memberikan pemahaman baru yang bisa mengubah konteks (pemahaman umum). ${ }^{14}$ Sebelum sesuatu fenomena budaya diterangkan (enklaren), dipahami (verstehen) agar keterangannya benar dilandasi makna kebudayaan yang ditelitinya, mendekati gagasan pemikiran pemangku budaya

Dalam kaitan ini Lewis R.Binford melihat inti meaning (makna) berada dalam tatanan konteks fungsional yakni komponen religi dari suatu sistem, maka wujudwujud yang tampak secara fisik adalah rasional ideologis yang direpresentasikan di dalam sistem kebudayaan. Jikalau demikian, kebudayaan Sunda dan unsurunsurnya yang kerap cenderung berbeda adalah makna dari sistem kepercayaan Sunda Wiwitan atau Jati Sunda. Inilah sesungguhnya jiwa kabuyutan yang nampak kepada kita sekarang. Maka kabuyutan bukan semata istilah atau penamaan melainkan wadah keyakinan yang sarat kandungan konsep, gagasan mental, spiritual yang mencerminkan jatidiri Urang Sunda.

Karena itulah berbicara kabuyutan dan Sunda Wiwitan sebagai unsur keyakinan Urang Sunda dihadapkan ke berbagai permasalahan epistemologis fundamental. Apakah harus bertolak dari keyakinan bahwa gagasan teoritis dalam pengetahuan ilmu sosial budaya universal seperti ilmu pengetahuan alam, atau terikat pada kebudayaan dimana gagasan itu dicanangkan. Ataukah diteruskan dengan pertanyaan apakah kebudayaan suatu masyarakat atau kelompok sosial merupakan suatu sistem yang dihayati oleh warganya sehingga pemahaman tentang lingkungan sosial dan biofisika bersifat seragam; ataukah masing-masing warga memiliki pemahaman sendiri-sendiri yang tidak perlu sama dari satu warga ke warga yang lain?

\footnotetext{
"Koentjaraningrat (1986), Peranan Local Genius dalam Akulturasi, dalam Ayatrohaedi (peny.) Kepribadian Budaya Bangsa (Local Genius), Pustaka Jaya. Halaman 80-90. Dijelaskan bahwa wujud dan isi kebudayaan secara universal mempunyai tiga wujud yaitu i) wujud gagasan (cullural system); 2) wujud aktivitas (social system); 3) wujud benda atau materi (material culture). Sedangkan isi kebudayaan meliputi tujuh unsur (sistem) yaitu sistem bahasa, sistem teknologi, sistem ekonomi, sistem organisasi sosial, sistem pengetahuan sistem religi, dan sistem kesenian. Semua yang diuraikan Koentjaraningrat diacu dari berbagai pendapat para ahli Antropologi dunia.l. J.j.Honingmann (1959) dan C.Kluckhohn (1953).

: Soerjanto Poespowardojo (1989), Strategi Kebudayaan, Suatu Pendekatan Filosofis. Diterbitkan hekerja-sana dengan LPSP (Lembaga Pengkajian Strategi dan Pembangunan), Jakarta, P'T Gramedia
} 
Kiranya sebagaimana hakekat setiap budaya, maka Urang Sunda pun memiliki asas dasariah sama dengan budaya-budaya lain di Nusantara. Pokok pembicaraan tentang kabuyutan, Sunda Wiwitan Tatar Pasundan dan permasalahannya akan disorot melalui bagaimana Urang Sunda (anthropos) di dalam ekosistemnya (oikos) merepresentasikan pengalaman, pengetahuan dan daya ciptanya (teknos) sebagai kepribadian (kebudayaan) Urang Sunda (ethnos). Dalam ekosistemnya Urang Sunda mendapat alat-alat konseptual atau perangkat untuk merumuskan pengalaman-pengalamannya yang diperoleh atau dimiliki sejak masa paling awal. Baik sebagai realitas yang kelihatan (benda: kabuyutan), maupun realitas tidak kelihatan lalu dihadirkan ke dalam simbol-simbol tertentu sesuai pengalaman Urang Sunda.

Ditegaskan Magetsari (1980) bahwa dikala pemangku budaya/pelaku budaya merealisasikan religious belief (core) kedalam simbol-simbol tertentu, gagasan tentang bentuknya telah dialami pencipta. Maka bentuk-bentuk yang nampak tiada lain hasil pengalaman keagamaan-nya. Pendekatan yang layak digunakan atas sisa aktivitas budaya (record) adalah dengan melibatkan peranh si peneliti layaknya seorang detektif yang memecahkan peristiwa melalui bekas-bekas yang ditinggalkan oleh si pelaku peristiwa budaya untuk dapat merekonstruksi seluruh peristiwa secara lengkap. ${ }^{15}$ Dalam pengertian luas keagamaan di sini sesungguhnya tidak hanya mencakupi apa yang disebut "agama" terrmasuk juga kepribadian (pengalaman kebudayaan). Di dalam realitasnya, pengalaman sejarah Urang Sunda sebagai kelompok etnis memiliki kodrat menghuni Tatar Pasundan, di kawasan dataran tinggi dikelilingi pegunungan yang membentang barat-timur sebagai dataran tinggi Parahiyangan, tahta semayam para leluhur sehingga menyebut tanah leluhurnya Lmah Parahiyangan.

Bertentangan dengan asumsinya semula, Ayatrohaedi kemudian menyatakan bahwa "bangunan suci Urang Sunda tidak selalu harus diidentifikasi kepada

\footnotetext{
13 Daud aris Tanudirjo (1994), Epigrafi Indonesia dalam Kerangka Fikir Pasca-Modernisme, Berkala Arkeologi, Evaluasi Data dan Interpretasi Baru Sejarah Indonesia Kuna (Dalam Rangka Purna Bhakti Drs.M.M. Soekarto Karto Atmodjo), Yogyakarta, 23-24 Maret, Tahun XIV, Edisi Khusus, halaman 10-16.

14 Ibid. Catatan 26.
} 
bangunan dengan artefak atau struktur seperti bangunan suci yang dimengerti masyarakat umum. Atau bangunan lengkap dengan fondasi, dinding dan atap, melainkan lahan bukit alam atau sengaja dibuat sebagai lambang suatu bukit (bukit buatan) dengan vegetasi hutan yang dibiarkan tumbuh alami"16 Kenyataannya, pusat-pusat pemujaan Urang Sunda ditemukan terletak pada suatu bukit, gunung, dataran tertinggi dari sekitarnya dan yang menjadi batas lahan suatu pemukiman dimanapun letaknya yang sarat sumberdaya alam dipilih sebagai (lahan) kabuyutan. ${ }^{17}$

Diterapkannya konsep pemilihan dan penempatan pusat keagamaan di masa lalu umumnya didasarkan atas pertimbangan lingkungan atau faktor ekologis semata baik terletak dekat sungai atau suatu bukit. Lahan-lahan ekologis merupakan sumberdaya alam utama menunjang kehidupan manusia (Moendardjito 1993). ${ }^{18}$ Namun senarai pernyataan Noerhadi Magetsari (1980): ${ }^{19}$

"Dilihat dari bekas-bekas penghidupan yang ditinggalkan manusia, kita lihat bahwa bagian terbesar dari peninggalan berupa bekas kehidupan keagamaan. Untuk keperluan penghidupan keagamaannya manusia tidak segan-segan untuk melukis dinding yang 5-7 meter tingginya dalam kegelapgulitaan gua, mendirikan bangunan-bangunan besar yang kalau dilihat dari teknologi modern pun sangat sukar untuk melaksanakannya. Sebaliknya peninggalan dari kehidupan sehari hari sedikit sekali bekas-bekasnya"

Berdasarkan asumsi itu, kajian (penelitian maupun pembicaraan) masalahmasalah kebudayaan sebagai unsur pokok adalah keagamaan Urang Sunda dengan aspek-aspeknya. Bagi arkeologi, kebudayaan dipelajari melalui record masa lalu dengan berlandaskan warisan aktivitas keagamaan. Pengertian keagamaan tidak

\footnotetext{
1s Tbid. Noerhadi Magetsari 1980:502,

${ }^{16}$ Drs. Suhendra Yusuf M.A. (1988), Fonetik dan Fonologi. Penerbit PT Gramedia Pustaka Utama, Jakarta.

17 Tulisan Ayatrohaedi ini terbit dalam Harian (Media Cetak) Pikiran Rakyat, Bandung, Hari Selasa, tanggal 22 Mei tahun 2001, halaman 21 .

${ }^{18}$ Moendardjito (1993), Pertimbangan Ekologi Dalam Penempatan Situs Masa Hindu-Buda Di Daerah Yogyakarta, Kajian Arkeologi-Ruang Skala Makro. Disertasi (Program Pasca Sarjana UI) ${ }^{19}$ Nurhadi Magetsari (1980), Kemungkinan Agama Sebagai Alat Pendekat Dalam Penelitian Arkeologi, makalah dalam Pertemuan Ilmiah Arkeologi(PlA), Cibulan,21-25 Februari 1977.Jakarta:Pusat Penelitian Purbakala dan Peninggalan Nasional. Halaman 498 - 504.
} 
harus dirujuk sebagai kepercayaan semata, tetapi juga keyakinan dan kepribadian budaya suatu bangsa yang menjadi jiwa kebudayaan secara universum. Maka sejauh apapun meneliti kebudayaan, tanpa memahami lebih dahulu keagamaannya (religious beliefbehind) akan sia-sia. Kita tidak mampu mengerti untuk apa suatu benda dibuat atau mengapa sesuatu peristiwa sejarah terjadi. Juga pemilihan lahan dan penempatan suatu bangunan bukan didasarkan pertimbangan ekologis semata, tetapi ada landasan lebih ini yakni keyakinan (kepribadian) yang disebut religious belief itu.

Pengalaman religious belief ini yang menyebabkan hadimya kabuyutan selaras arti kata kabuyutan yakni puseur dangiang, paragi ngahiyang, tahta para hyang (leluhur=karuhun), inti tertinggi bagi Urang Sunda (parahiyangan). Merujuk pengertian tahta Hiyang, maka bangunannya adalah segala sesuatu yang telah disediakan dari leluhur yang dipahami dengan tanpa merubah apapun atas warisan leluhur (melestarikan pikukuh =aturan) dan seluruh perangkat (adat istiadat) yang - telah ditanamkan leluhurnya (para hiyang). Maka bangunan bercorak tradisi megalitik yang telah ada dan tersedia dengan segala perangkatnya tata caranya yang jelas merupakan pengalaman nyata para pendahulu Urang Sunda itulah yang tetap dilestarikan dan direalisasikan sebagai Sunda Wiwitan, Sunda Yang Asal, Yang telah ada sejak awal (Pikukuh Karuhun). Karena itu bangunan suci Urang Sunda disebut Kabuyutan bukan yang lain karena memang dari dan melanjutkan tradisi Leluhurnya.

Petunjuk nyata bahwa alam pemikiran tradisional mereka memahami secara lebih mendalam tentang faktor penting dari ekosistem meliputi kombinasi empat elemen yang digunakan untuk memilih dan menempatkan situs-situs keagamaannya relatif tepat. Jarak ke air, ecotone, tingkat elevasi tanah dan tingkat kemiringan lahan adalah ekosistem yang paling memenuhi tuntutan teknologi dan ekologi.

\section{Beberapa Kabuyutan Urang Sunda: Percontoh Utama}

\subsection{Kawasan Gunung Gendut (Lebak)}

Sampai sekarang di kawasan Lebak provinsi Banten masih dapat disaksikan sejumlah sisa aktivitas Lebak Cibedug, Kosala, Batu Sirit dan Ciwongwongan 
Sasaka Domas di Kenekes yang menonjolkan corak tradisi megalitik berupa teras menempati bukit dengan puncak bukit sebagai punden. Tiap-tiap punden dipancangkan batu tegak yang cukup besar dan tinggi dengan bentuk alami (menhir), kecuali batu tegak di situs Batu Sirit telah dibentuk phallus. Bukan suatu kebetulan jikalau tiap-tiap situs adalah juga bukit-bukit yang terletak pada mata angin yang mengesankan berpusat ke Gunung Gendut sebagai gunung tertinggi. Asal (hulu) sungai yang mengalir di kawasan ini, terlindungi vegetasi hutan yang sangat lebat. Kosala letaknya di Pasir Sangka (Pasir Oray) di lereng tenggara Gunung Gendut (1281 m), Batu Sirit di Gunung Dangka tepat arah timur Gunung Gendut, Lebak Sibedug di lereng barat daya Gunung Bapang (1045 m), Pusaka (Sasaka) Domas (Kanekes) di lereng Gunung Kendeng $(926 \mathrm{~m})$ tepat arah barat Gunung Gendut.

Selain bangunan tradisi megalitik juga terletak insitu prasasti di tepi (sungai) $\mathrm{Ci}$ Danghiyang yang dipahatkan pada batu alam dengan aksara Pallava dan bahasa Sanskrta. Isinya mengumumkan bahwa "Purnnawarmman raja Tarumanagara sebagai panji segala raja-raja”. Purnawarman adalah penguasa tertinggi Tarumanagara, kerajaan tertua yang mengawali sejarah Tatar Sunda bahkan di Pulau Jawa (abad ke-4-5 Masehi). Dalam hubungan konteks, warisan budaya bercorak tradisi megalitik dan keberadaan prasasti tentu bukan kebetulan semata tetapi sudah seharusnya memiliki hubungan antara satu dan lainnya Tidak semata Purnawarman menegakkan prasasti batu berupa pengumuman tertulis di kawasan Lebak jikalau bukan karena bangunan-bangunan tersebut memiliki kaitan langsung dengan Tarumanagara.

Di dalam Laporan Penelitian Balar Arkeologi Bandung (2005), Luthfi Yondri (Ketua Tim) dicatat bahwa di utara prasasti Cidanghiyang, dalam aliran $\mathrm{Ci}$ Danghiyang sampai sekarang masih dapat dilihat batu berpahatkan gambar sepasang telapak kaki, batu bentuk kura-kura, batu kasur yang cukup lebar dan besar untuk ditiduri tubuh manusia dan batu dakon. Radius $3 \mathrm{~km}$ dari letak prasasti tersebar bongkah-bongkah batu, dolmen-dolmen, batu-batu datar (dampar, pada ageung) dan batu-batu tegak berukuran cukup besar. ${ }^{20}$ Lahan dimana prasasti Cidanghiyang merupakan meander sungai dan muara aliran sungai-sungai kecil yang ada di sekitarnya, di lingkungan perbukitan subur, yang sampai kini ditenukan (insitu) 
sisa-sisa struktur yang kondisinya telah hancur dan nampak serakan bongkahbongkah batu yang tidak beraturan walau terkonsentrasi pada lahan tersebut. Beberapa bagian perbukitan diolah menjadi lahan pertanian penduduk, akibatnya artefak-artefak batu besar yang dahulu ada disini terpencar berjauhan, ada yang tergeletak begitu saja terpisah pada lahan-lahan pertanian.

Bagaimana konsekwensi Purnawarman dianggap pemuja Vishnu Triwikrama sedang-kan bukti satu-satunya fragmen kepala arca Vishnu dari situs Cibuaya [abad ke $7 \mathrm{M}$ - akhir Tarumanagara). Dari tujuh prasasti tersebut hanya satu saja (Ciaruteun A) yang menyebut "seakan-akan sepasang kaki dewa Vishnu" apakah harus diartikan raja Tarumanagara betul-betul memeluk Vishnu? Apakah harus diartikan masyarakat waktu itu menganut kepercayaan sama dengan rajanya. Keberatan lain adalah arca [Vishnu] "nan semata wayang" dirujuk masa Tarumanagara, baik bahan dan gaya seninya tidak ditemukan di Jawa, tetapi di luar pulau Jawa. Masalahnya belum terjawab jelas.

Ditunjang saksi langsung (tatra saksi) bernama Fa-H'shien (Cina) pernah mencatat bahwa "pada waktu itu di kerajaan Taruma (Tolomo) sangat sedikit penganut Hindu-Budha tetapi masyarakat setempat beragama buruk (kotor)". Menurut para sarjana "agama kotor" yang disebut oleh Fa-Hsien itu tiada lain kepercayaan yang ada sebelum kehadiran unsur pengaruh (inovasi) luar yakni India. Sistem kepercayaan dengan adat dan tatacara yang sangat jauh berbeda dengan kepercayaan Fa-H'shien yang dipengaruhi unsur India (Hindu-Buda). Pendapat [Fa-H'shien] semata ketidaktahuannya tentang sistem kehidupan dan keagamaan asli (pribumi) yang dianut sebagian besar masyarakat Tarumanagara (Soemadio 1976: 49-50).

Ada satu ganjalan untuk meyakinkan bukti itu adalah daerah Tolomo (lafal Cina untuk Taruma) mana yang didatangi musafir Cina Fa-H'shien ketika itu? Mengingat betapa luasnya kawasan Tarumanagara Kala itu. Jikalau prasasti-prasasti

\footnotetext{
30 Penulis ingin menyampaikan terima kasih sedalam-dalamnya kepada ketulusan Luthli Yondri M.Hum yang kini bekerja di Balar Arkeologi Bandung sebagai Peneliti Arkeologi (bidang) Prasejarah - yang telah meminjamkan laporan hasil penelitiannya di kawasan Lebak.
} 
dari masa Tarumanagara diletakkan sebagai bukti, maka kekuasaannya meliputi aliran Citarum bagian barat hingga ke kawasan Lebak? Lagipula secara palaeografis aksara prasasti Cidanghiyang sangat mirip pahatan aksara prasasti Tugu (CilincingJakarta). Walaupun tetap mempertimbangkan apakah pahatan aksara dua prasasti itu dikerjakan penulis prasasti (citralaikha) yang sama, apakah dua prasasti itu berasal dari satu masa karena kebiasaan prasasti-prasasti dari masa Tarumanagara tidak memakai pertanggalan. Dengan kata lain Apakah kawasan Lebak merupakan salah satu bukti kesaksian mata seorang Fa-H'shien. Mengingat sejauh penelitian dilakukan belum pernah diketahui bagaimanakah bentuk bangunan keagamaan masa Tarumanagara? Menurut akal sehat adalah sangat janggal bila sebuah kerajaan besar yang menguasai mandala Sunda waktu itu samasekali tidak memiliki bangunan monumental. Apalagi sampai saat ini belum ditemukan letak pusat kerajaan Taruma secara pasti.

Sarjana mengasumsikan Prasasti Tugu yang berisi keterangan lengkap dengan perangkat simbol-simbolnya nampak lebih "resmi" dibanding prasasti Cidanghiyang dan lainnnya itu karena berkait dengan pendirian ibukota (pusat kerajaan). Namun pada intinya prasasti-prasasti masa Tarumanagara secara umum isinya pengumuman tentang eksistensinya ke dunia internasional. Kala itu pula India tengah menjadi pamor kekuatan budaya panggung internasional kawasan Asia. Prasasti-prasasti Tarumanagara menggunakan bahasa Sanskerta dan aksara Palawa karena bertujuan politis (lingua franca) seperti disebutkan H.GQuaritch Wales "in conditioning the recipients to foreign stimulus". ${ }^{21}$ Sejumlah besar warisan budaya Cibuaya dan Batujaya (Karawang Bekasi) oleh para sarjana diperkirakan masa Tarumanagara antara lain dihubungkan dengan keterangan prasasti Tugu, beberapa fragmen prasasti pendek kertas emas, ${ }^{22}$ fragmen prasasti tanah liat bakar,

\footnotetext{
${ }^{21}$ Prasasti Tugu isinya menyebutkan bahwa raja Pumnawarmman membuat saluran air Candrabhaga, kemudian pada tahun ke-22 masa pemerintahannya ia menyelesaikan saluran air yang kedua Gomati (panjang 6.122 busur = kurang lebih $11 \mathrm{~km}$ ), sal;uran terrsebut mengalir melalui istana kerajaan yang termashur dan selanjutnya bermuara ke laut. Menurut H.Kem (1917) dan Poerbatjaraka (1952:14-15) Candrabhaga adalah Kali Bekali (sekarang) dan dekat kali ini pulu letak istana kerajaan yang termashur itu. N.J. Krom (1926; 1931); J.Noorduyn dan H.Th. Verstappen (1972) menyimpulkan bahwa ibukota Tarumanagara besar kemungkinan di daerah Tugu dan sekitamya serta tidak jauh dari letak Kali Cakung yang mengalire di daerah Sampai Metropolitan, Jakarta 1992-1993. Pemda DKu Jan Pemukiman Jakarta Dari Masa Bercocok Tanam dan Budaya, Lembaga Penelitian Universitas Indonesia).
} 
dan meterai teracotta. ${ }^{23}$ Sejauh itu rupa-bentuk bangunan suci situs Batujaya dan Cibuaya belum diperoleh identitas jelas, karena sebagian besar yang tersisa berupa struktur-struktur bata yang masih sulit dijelaskan. Kalau boleh disebut Cibuaya dan Batujaya merupakan satu-satunya kompleks bangunan berbentuk batur di Tatar Sunda dengan bahan utama dari alam berupa tanah liat yang sengaja dirubah dan dibentuk sesuai keinginan atau kebutuhan si pemangku budaya. Di Kompleks situs ini pula ditemukan berbagai artefak yang sangat kental pengaruh asing, sangat jauh berbeda dengan bangunan-bangunan yang besar Urang Sunda bercorak tradisi megalitik. ${ }^{24}$ Begitupun prasasti-prasastinya berpahatkan aksara yang tidak biasa ditemukan di Jawa. Di sekitar pantai pesisir utara Jawa, tidak jauh dari (Cilincing) lokasi ditemukannya prasasti Tugu, terletak situs hunian wanisan Buni. Analisis Carbon Dating (C14) menunjuk periode yang sejaman dengan situs Pejaten (1000 s.M.— 500 M) yakni dari masa perundagian (prasejarah) hingga masa Tarumanagara (Klasik). ${ }^{25}$

- Informasi pertanggalan atas warisan budaya Tarumanagara lainnya dicatat oleh Bagyo Prasetyo (1995) dari situs religi Pasir Angin yang antara lain dicirikan oleh monolith, alat-alat upacara dari perunggu kapak, genta, tongkat), topeng emas ) alat-alat besi (kapak, tongkat, tombak), artefak emas (topeng upacara), kaca, manik-manik, beliung dan lain-lain. Semua artefak merupakan hasil ekskavasi, tatkala ditemukan tersusun mengelompok bervariasi memanjang dan membulat.

\footnotetext{
22 Penulis menyaksikan sendiri berapa dari prasasti kerlas emas itu kini disimpan di Museum Pemda. Kebudayaan Serang, Banten, Jawa Barat, dituliskan dengan aksara Pallawa, masih belum dapat dibaca, tetapi besar kemungkinan isinya tentang mantra (?)

23 Peter Ferdinandus, Aspek-Aspek

24 Di situs Cibuaya dan situs Batujaya ditemukan berbagai artefak yang jelas menunjukkan dari luar Indonesia diantara-nya prasasti yang dipahatkan pada tembikar (diduga dari abad ke-4 dengan gaya Kedah); sejumlah besar meterai tembikar bercap gambar Budha dan bertulisan (aksara Pallawa dan bahasa Sanskerta) yang diperkirakan dari salah satu budaya di negara Asia Tenggara. Kiranya kompleks bangunan yang terletak di pesisir utara Jawa (Batujaya dan Cibuaya) mungkin bukan untuk dan oleh pemangku budaya Sunda, melainkan bagi orang-orang luar (dari berbagai negri) yang datang dan (mungkin) menetap sementara di Indonesia dengan berbagai keperluan (berdagang?).

25 Temuan terpenting situs Cilincing berupa pecahan gerabah dari berbagai jeni wadah juga manik-manik; gerabah jenis wadah juga terdapat di situs Buni juga beliung persegi, benda-benda perunggu dan besi, gelang perunggu, perhiasan emas, dan tulang belulang manusia.

26 Bagyo Prasetyo (1995), Situs bukit Pasir Angin, Kabupaten Bogor, Jawa Barat: Suatu Kajian Fungsi Atas Dasar Konteks, Tesis S-2 Program Studi Arkeologi Bidang Ilmu Pengetahuan Budaya Program Pasca Sarjana, Universitas Indonesia.
} 
Situs Pasir Angin merupakan pusat kegiatan keagamaan yang berlangsung cukup lama sejak periode prasejarah (B.C.) - periode Klasik (A.D.) ditunjang kondisi kelayakan situs yang tinggi, lahan bukit datar dikelilingi meander sungai. ${ }^{26}$ Fakta bahwa sebagian besar prasasti-prasasti batu di Tatar Sunda hampir selalu insitu ditemukan di situs-situs dimana terletak kabuyutan, apakah CidanghiyangLebak dan sekitarnya dapat diletakkan sebagai bukti kabuyutan tertua (abad IVVMasehi). Enam prasasti dari masa Tarumanagara lainnya ditemukan di kabupaten Bogor (prasasti Jambu, prasasti Ciaruteun, prasasti Kebonkopi, prasasti Muara Cianten, dan prasasti Pasirawi) beraksara Palawa dan berbahasa Sanskerta yang ditata ke bentuk Sloka (puisi) bermetrum Anustubh juga Sragdhara ${ }^{27}$ Prasastiprasasti itu ditemukan di kawasan situs Pasir Angin (Pasir Koleangkak). ${ }^{28}$

Tidak berlebihan jika dikatakan bahwa Tarumanagara merupakan "peletak dasar" yang selanjutnya menentukan sikap dan arah kebudayaan Tatar Sunda, sekalipun ada bukti pengaruh kebudayaan (India) yang dikala itu menjadi alat komunikasi intemasional (khususnya bahasa dan agama) ternyata tidak memieu negara Taruma menjadi "bangsa tiruan" atau selalu meniru, melainkan berdaulat dan berakar kepada kebudayaan sendiri baik fisik maupun mental spiritual. Kenyataannya bangunan bercorak tradisi megalitik inilah yang tetap bertahan dan berlanjut hadir hingga ke masa lebih kemudian sebagai kekuatan "yang sulit digoyahkan?"

\footnotetext{
27 Hasan Djafar (1988), di dalam karyanya berjudul Daftar Inventaris Peninggalan Arkeologi Masa Tarumanagara, Jakarta: Universitas Tarumanagara. Proyek Penelitian Terpadu Sejarah Kerajaan Tarumanagara: Sub Proyek Penelusuran dan Inventrisasi Peninggalan Tarumangara, memilab prasasti Ciaruteun sebagai prasasti Ciaruteun A yang berpahatkan aksara palawa, dan prasasti Ciaruteun B yang berpahatkan gambar pilin, padahal kedua jenis pahatan ini digoreskan pada batu yang sama. Karena ia melihat pada batu lain di tempat sama yang juga bergoreskan gambar pilin, maka ia mengasumsikan pilin tersebut adalah aksara yang disebut krulleters atau conch-shell script (aksara sangkha). Di sini penulis tidak mengacu pada pembagian tersebut dan meletakkan prasasti Ciaruteun saja, dengan dasar anggapan gambar pilin dan umbi-umbian yang distilir sulur-suluran itu termasuk ragamhias geometrik, tipe ragamhias tertua yang secara universal ditemikan di seluruh belahan dunia seperti yang dinyatakan oleh van der Hoop. ${ }_{28}$ R.M.Ng.Poerbatjaraka, Riwayat Indonesia I, 1921, berasumsi prasasti-prasasti masa Tarumanagara yang ditata dengan metrum Anustubh dan Sragdhara begitu sempuma yang biasa dipakai oleh Brahmana tingkat tinggi, tetapi juga sangat sulit dipelajari begitu saja kalau bukan oleh si pemilik budayanya sendiri, maka ia menyimpulkan bahwa prasasti-prasasti (Tarumanagara) tersebut memang dibuat oleh Brahmana India yang sengaja diundang oleh raja (Pumawarman) Tarumanagara, jadi bukan oleh orang Indonesia.
} 
Masa lalu Urang Sunda terpampang jelas pada salah satu sukubangsa yang kini masih hidup dan dapat disaksikan sekarang melaksanakan upacara keagamaan dengan tradisi dan kepercayaan Sunda Wiwitan yakni masyarakat Kanekes (Baduy di Banten Selatan). Sampai sekarang di Kanekes terdapat kabuyutan Jati Sunda (Sunda Asli) sebagai bangunan upacara Sunda Wiwitan. Saleh Danasasmita dan Anis Djatisunda diizinkan Puun mengunjungi tempat suci Sasaka Domas meski sampai undakan ketujuh dan tidak sampai ke punden. Dituturkan bahwa Pusaka Sasaka (Pada) Ageung atau Sasaka Domas Sasaka, pusat upacara keagamaan atau kabuyutan Jati Sunda. Sasaka tempat muja masyarakat Kanekes pada tiap bulan kelima kalender Urang Kanekes. Terletak di Gunung Pamuntuan pada aliran hulu $\mathrm{Ci}$ Ujung, tepatnya pada sudut kelokan sungai yang membelok ke arah timur, pada lereng tepian sungai sebelah utara. Bangunan tersebut terdiri dari tujuh undakan (teras) disusun menyerupai petak-petak sawah". Tiap-tiap undakan teras dibatasi penahan (hambaro = tanggul) yang disusun dari batu sungai yang sengaja dibiarkan melumut tebal. Lingkungan Sasaka berupa menghutan lebat, subur dengan berbagai tumbuhan tua. Di undakan pertama terdapat batu disusun seperti "kuburan". Undakan 2-6 terpancang batu-batu tegak (menhir) diantaranya berukuran tinggi $2 \mathrm{~m}$ (undakan ke-4). Salah satu sudut undakan ke-7 terdapat batu lumpang bergaris tengah $90 \mathrm{~cm}$ yang berisi air disebut Sanghiyang Pangumbahan. Sebenarnya tiap undakan memiliki nama namun tidak diketahui kecuali undakan ke-2 di selatan disebut Sanghiyang Gerit. Dimana tepatnya Sasaka Pusaka Buana atau Sasaka Domas masih rahasia, tidak sembarang orang dapat memasukinya kecuali Puun dan kepercayaannya. ${ }^{29}$ Menurut C.M.Pleyte (1909) domas = jumlah 800 , asal mula Urang Kanekes, ${ }^{30}$ domas juga artinya pusaka suci, selaras arti fungsinya sebagai tahta para Hiyang. ${ }^{31}$ Sasaka Pusaka Buana tempat terletak Arca Domas oleh Sri Rahayu Budiarti (1983) dituturkan

\footnotetext{
29 Puun merupakan kata jadian dari akar kata un (bahasa Sunda Kuno) (= hormat) kemudian timbul umun (= menyembah) dan puun (= orang atau seseorang yang disembah). Akan tetapi Puun juga berasal dari Puhun (Sunda Kuno) artinya pohon, pokok, sumber setara dengan pengertian tangtu = cikal bakal karena peristiwa puhun $>$ puun sama halnya dengan tahun $>$ taun: nohong $>$ noong; cihaliwung $>$ ciliwung di dalam ucapan Urang Sunda sekarang.

${ }^{30}$ C.M.Pleyte (1909), Artja Domas, Het Zielan der Badoejs, TBG. 51. Halaman 494-527.

3) Saleh Danasasmita dan Anis Djatisunda (1986), Kehidupan Masyarakat Kanekes. Bagian Proyek Penelitian dan Pengkajian Kebudayaan Sunda (Sundanologi). Direktorat Jendral Kebudayaan. Bandung: Departemen Pendidikan dan Kebudayaan.
}

Berkgafa Arkeologi Tafun XXVIEdisi No. 1/Mei 2006 
berdasarkan kesaksian dan wawancara Norman Edwin dengan pemangku Budaya (Kanekes) bahwa Sasaka Pusaka Buana (Arca Domas) sebenarnya terdiri 13 undakan:

1. Undakan ke-13 (bawah), tempat berkumpul arwah menuju Lemah Bodas;

2. Undak ke- $6,-7,-8,-9,-10,-11,-12$ adalah tempat istirahat kelima putra Batara Tunggal; undak ke-6 ditemukan batu lumpang (Sanghiyang Pangumbahan) dan tonggak batu

3. Undak ke-4 dan ke-5 kosong

4. Undak ke-3 terdapat 6 batu tegak (dianggap cucu Batara Tunggal)

5. Undak ke-2 disebut Lmah Bodas tempat Batara Cikal (anak Batara Tunggal), pada tembok selatan terdapat lubang tempat arwah masuk (Sanghiyang Gerit),

6. Undak teratas terdapat tumpukan batu, tiang batu dan menhir (tinggi 2,5 m) tempat tersuci yakni tahta Batara Tunggal.

\section{2. Kawasan Gunung Sawal (Ciamis)}

\subsubsection{Kabuyutan Kawali}

Situs Kabuyutan Kawali kondisinya kini tidak lagi tampak sebagaimana mestinya, dan apa yang tampak kini adalah benar-benar bentuk campur tangan hasil pemugaran berulang-kali oleh PemDa. ${ }^{32}$ Namun berdasarkan catatan terdahulu dan hasil penelitian penulis dapat dijelaskan bahwa Kawali merupakan teras berundak dengan elevasi tiap-tiap teras $4^{\circ} .{ }^{33}$ Terletak di lereng timur kaldera gunung Sawal dengan ketinggian 363 meter dpl. Diapit Ci Kadongdong di utara dan $\mathrm{Ci}$ Bulan di selatan yang mengalir mengelilingi situs bertemu di tenggara situs. Warisan budaya situs Kawali menggunakan batu-batu besar berukuran bongkah dan kerakal andesit ada yang diletakkan terbaring (baru datar) dan ada yang tegak berdiri (menhir). Juga artefak-artefaknya tidak dibentuk khusus tapi memanfaatkan bentuk dan kondisi alaminya (kecuali batu pangeunteungan). Enam diantaranya bergoreskan aksara dan bahasa Sunda Kuna (prasasti) dan tidak satupun mencantumkan angka tahun, kecuali disebutkan nama Nusiya Mulia (Sunda: Yang

\footnotetext{
32 Lihat Iaporan Sudarti Priyono

${ }^{33}$ Penulis berulangkali melakukan penelitian arkeologi di situs Kawali sejak tahun 2001 sampai 2004.

${ }^{24}$ Berdasarkan catatan Sdr. Deni (Kasi Kebudayaan kabupaten Ciamis) situs-situs yang terdaftar sebagai BCB sampai tahun 2004, situs-situs di Kabupaten Ciamis seluruhnya berjumlah 305 situs
} 
sangat Agung atau Yang Terbesar) Prebu Raja Wastu (prasasti Kawali satu). ${ }^{34}$

Teras pertama terdapat punden yang dihubungkan pavedstone (suatu tatanan batu/ jalan ke arah pintu teras kedua). Terasnya disusun dari batuan lempeng, kerakal andesit dan batuan boulder yang ditata sebagai lantai teras. Punden ini membujur utara-selatan dengan bentuk persegi panjang namun sebagian dari batu penyusun bagian lebar telah hilang. diberi pagar keliling bambu dan dua pintu masuk terletal di utara dan selatan, masing-masing pintu diberi 4 undakan tangga dari batuan lempeng.

Teras kedua (lebih rendah dari teras pertama) berorientasi baratlaut:

1) Batu Jungjung (batu kursi desolit) merupakan dua batuan lempeng disusun menyerupai tempat duduk (kursi) terletak 6 meter di baratdaya pintu masuk teras kedua (pelinggih), sebuah lainnya berada di sisi selatan batu pertama, sekeliling artefak diisi sejumlah batuan lempeng dan batuan boulder disusun

- sebagai lantai sejajar permukaan batu kursi

2) Prasasti I bentuk batu datar persegi panjang tidak beraturan dengan posisi terbaring. Tulisan dipahatkan pada sisi muka (10 baris) ditandai adeg-adeg (pembuka); bagian tepian dipahatkan satu baris tulisan beraksara dan bahasa Sunda Kuna

3) Prasasti II berupa lempeng batu persegi panjang, bagian atas meruncing dengan posisi berdiri tegak. Tulisannya pada sisi muka berisi 7 baris beraksara dan bahasa Sunda Kuna.

4) Prasasti III merupakan temuan tahun 1995 (juru kunci) para sarjana mengkatagori prasasti Kawali VI. Isi pesannya merupakan lanjutan prasasti I dan II, maka dalam tulisan ini disebut prasasti III. Bentuk batunya tidak beraturan dengan posisi rebah dan tulisannya dipahatkan satu sisi berisi 6 baris beraksara dan bahasa Sunda Kuna.

5) Batu Tapak atau prasasti IV (penduduk: kolenjer) bentuk batunya hampir segilima tidak sama sisi.Berisi pahatan gambar $45 \mathrm{kotak}$ (5 disusun vertikal dan 9 kotak horizontal) di luar kotak (kanan) terdapat cap tangan kiri, sepasang telapak kaki dan sebaris prasasti berbunyi anggana beraksara dan berbahasa Sunda Kuna. 
Teras ketiga terdapat batu Panyandungan (prasasti V) berupa batu tegak (menhir) ditopang batu. Salah satu sisi pemukaannya berpahatkan tulisan beraksara dan berbahasa Sunda kuna terdiri dari dua baris Samg Hiyang Lingga Hiyang; batu Panyandaan atau prasasti Kawali VI (10 meter di tenggara batu panyandungan berbentuk batu tegak berukuran agak lebih lebar dari batu panyandungan). Salah satu bagian datarnya menghadap selatan dipahatkan dua baris tulisan beraksara dan berbahasa Sunda Kuna Sang Hiyang Lingga Bingba. Di selatan batu panyandaan ada menhir kecil dan batu Pangeunteungan berpenampang persegi, bagian per-mukaan datarnya dihiasi pelipit, bagian tengahnya berlubang segitiga dan selalu terisi air, penduduk setempat menyebut artefak ini paragingeunteung (tempat bercermin).

Teras Keempat dan Teras Kelima tidak diketahui lagi namun disekeliling teras ketiga terdapat sejumlah besar serakan lepas batu kerakal andesit "menyerupai" menhir kecil dan besar yang menurut penduduk yang telah sejak awal mereka menghuni Kawali. Serakan itu dahulu adalah batu penyusun terasteras bangunan yang terserak di kwadran timurlaut (483); baratlaut (240); tenggara (75). Jumlah yang terhampar berkisar 798, sebagian besar lainnya terpendam dan hilang Kwadran baratdaya belum diketahui sebab lahan ini hingga ke pintu gerbang difungsikan sebagai paved-stone, hasil pemugaran Pemda. ${ }^{35}$

\subsubsection{Kabuyutan Susuru}

Kabuyutan Susuru ditemukan tahun 2000 di dusun Buner, desa Kertabumi, kecamatan Cijeungjing di tenggara pematang lereng gunung Sawal. Luas situs 12,5 ha. Mengisi lahan bukit, ketinggian sekitar $500 \mathrm{dpl} \mathrm{dibatasi} \mathrm{Ci} \mathrm{Muntur} \mathrm{(baratlaut)}$ dan Ci Leueur (baratdaya). Sungai-sungai ini bertemu di timur ketinggian 140150 dpl mengapit situs Susuru dan yang menyebabkan situs dikelilingi tebing-tebing sangat curam. ${ }^{36}$ Bangunannya merupakan teras-teras yang dibuat dari batuan bongkah beku volkanik dan breksi volkanik hasil satuan batuan hasil gunung api gunung Sawal. Temuan terdiri dari batu tegak (menhir), batu pangcalikan, sumur batu, punden berundak, manik-manik, keramik dan goa pertapaan pada tebing dan dinding curam. Bangunan diposisikan sesuai kondisi alaminya merupakan 5 
teras- dengan elevasi $5^{\circ}$ berorientasi $\mathrm{S} 32^{\circ} \mathrm{E}$ barat laut.

1. Teras Pertama (paling bawah) terdapat batu besar berbentuk segilima tidak sama sisi dengan permukaan bagian atas datar.

2. Teras Kedua (arah selatan punden) terdapat tujuh batu letaknya berdekatan dan diberi pagar bambu. Salah satu batu terbesar bentuknya hampir bulat permukaan atas datar, garistengah $1.70 \mathrm{~m}$, tebal $0.38 \mathrm{~m}$, batu-batu lain berukuran lebih kecil,

3. Teras Ketiga (lebih ke selatan dari teras kedua) terdapat batu berbentuk agak lonjong $1.85 \times 1.53 \times 0.34 \mathrm{~m}$ dengan permukaan datar. Tiga batu bentuknya agak bulat berukuran lebih kecil diletakan berdekatan

4. Teras Keempat (selatan batu ketiga), terdapat batu besar bulat-lonjong diameter $1.94 \mathrm{~m}$, tebal $0.44 \mathrm{~m}$. Permukaan atas batu datar, sebuah lainnya berukuran kecil.

5. Teras Kelima (lahan tertinggi) terletak di sudut tenggara tepat searah dengan sudut pertemuan (sungai) Ci Leueur dan Ci Muntur lebih merupakan teras, - kurang lebih 1,5 m di selatan terdapat batu terbesar bentuknya alami dengan permukaan atas datar (batu utama) - teras ini merupakan punden.

\subsubsection{Kabuyutan Gunung Padang}

Terletak di kampung Sukahurip, desa Sukaresik, kecamatan Cikoneng pada lahan bukit (Sunda: Pasir) sekitar 500 meter dari jalan desa dikenal penduduk sebagai pertapaan Ajar Sukaresi. Situs ini menempati lahan bukit terletak pada ketinggian 423 meter dpl., pada koordinat $07^{\circ} 17^{\prime} 8^{\prime \prime}$ LS dan $108^{\circ} 15^{\prime} 5^{\prime \prime}$ BT. Lingkungannya rindang oleh tanaman keras yang tumbuh alami dan sekitar situs

\footnotetext{
${ }_{35}$ Namun menurut Juru Pelihara (Mang Akub dan Mang Saleh) dikala Pemda memugar (a.1. mernbuat pavedstone dan tiang dan bangunan cungkup) lahan tersebut, didahului dengan ekskavasi hingga kedalaman $50 \mathrm{~cm}$ dari pernukaan tanah telah ditemukan sejumlah besar kerakal andesit dan boulder, yang menunjukkan sisa penyusun teras keempat dan kelima? Prasetyo mencatat jumlah teras bangunan di situs Kawali hanya tiga teras saja. Penelitian Kawali 2001-2004 berhasil mengungkap bahwa salah satu artefak di situs Kawali yakni Batu Tapak (penduduk setempat menduga kolenjer) disebut Prasasti Kawali 5 berpahatkan goresan gambar 5 baris (horizontal) x 9 biras (vertikal) memberi jawaban bahwa kabuyutan Kawali sebenamya lima undakan teras. Batu Tapak, selain dimaksudkan sebagai denah situs Kawali (dari lima teras), juga melambangkan anggana sebagaimana dipahatkan pada batunya. Falsafał Urang Sunda tentang pengetahuan jagatsemesta (makrokosmos) yang tereduksi dalam diri manusia sebagai pancaindriya (berjumlah 5) dengan lubang pengelurannya yang dalam bahasa Sunda disebut cungap (berjumlah 9). Jelas Batu Tapak merupakan denah sekaligus penggambaran simbol konsep ajaran Sunda Wiwitan. ?
}

${ }^{36}$ Laporan Balai Arkeologi Bandung 2000; Laporan Pusat Penelitian Arkeologi 2001. 
hingga sekarang masih digunakan sebagai tempat pemakaman umum. Sebagian besar makam menggunakan bahan material sama (kerakal andesit) yang digunakan Pertapaan Ajar Sukaresi. Penggunaan material nampak pada nisan dan beberapa jirat makam. Sebuah batu lempeng berukuran panjang 0,61 meter, lebar 0.46 meter dan tebal 0,03 meter memperlihatkan bahwa batu tersebut semula berasal dari situs pertapaan Ajar Sukaresi. Batu itu sebagai tempat meletakkan bunga para peziarah pada saat tertentu.

Menurut Juru Pelihara (Ma Enoh) Gunungpadang adalah petilasan tapa Prabu Ratu Galuh Ajar Sukaresi Permanadikusumah. Batu tapa tersebut berupa batu berbentuk lempeng berukuran panjang 1.10 meter $\mathrm{x}$ lebar 0.65 meter $\mathrm{x}$ tebal 0.08 meter. Kini tersimpan dalam cungkup permanen berukuran $4.40 \times 4.10$ meter yang dibangun pada tahun 1978. Bagian luar bangunan terutama bagian utara dan barat bangunan terdapat hamparan kerakal andesit. Jumlah kerakal andesit terbanyak terletak di sisi utara menyambung sampai ke bagian timur bangunan melanjut ke pintu masuk berupa benteng disusun dari kerakal andesit.

Situs ini merupakan bangunan berundak lima teras dengan elevasi relatif rendah. Teras tertinggi merupakan teras kelima terletak paling barat sejajar dengan batu petilasan "punden" dalam bangunan, teras keempat sampai teras pertama (terendah) berlanjut ke arah timur menuju ke pintumasuk halaman. Teras pertama, kedua dan ketiga tidak ditemukan dibatasi kerakal andesit, teras ke-empat, selain ditemuka sisa pagar batu pada salah satu sudut terdapat susunan batu persegi panjang. $\mathrm{Di}$

\footnotetext{
${ }^{37}$ Lokasi ini terletak di kaki bukit sisi tenggara, ketinggian 1163 meter di atas permukaan laut dengan posisi di sebelah barat jalan raya alternatif yang mengbubungkan wilayah Panjalu menuju Cikijing ke arah Majalengka. Koordinat situs pada posisi $07^{\circ} 0$ ' $52,7^{\prime \prime}$ lintang selatan dan $108^{\circ} 16^{\prime} 12^{\prime \prime}$ bujur timur. Jalan menuju bukit dimana terletak bangunan pusat ditemukan sekitar 14 batu menhir berserakan tidak beraturan dengan ukuran yang cukup spektakuler. Diantaranya yang terbesar berukuran sekitar panjang 1.90 meter dengan ketebalan salah satu sisinya 0.78 meter. Batu-batu tersebut pada umumnya bampir berbentuk segi lima dengan keadaan tumpang tindih. Sebaran "menhir" berukuran besar tersebut ditemukan di jalan setapak menuju bukit yang berbentuk hampir segi enam dengan ukuran panjang salah satu sisinya mencapai 2.20 meter. Batu tersebut letaknya dalam posisi rebah ke dinding bukit. Lebih masuk lagi ke lereng bukit ditemukan sebuah batu di sebelah kiri jalan setapak dengan posisi rebah ke ke arah barat laut. Bentuk batu hampir segi lina dengan ukuran panjang mencapai 3.16 meter dan ketebalan salah satu sisinya sebesar 0.50 meter. Tidak jauh dari lokasi sebelumnya, ditemukan lagi 3 (tiga) buah batu dengan jarak yang berdekatan, kecuali batu ketiga letaknya agak sedikit jauh dari dua batu pertama. Batu pertama berbentuk hampir empat
} 
dalam pagar batu terdapat susunan batu datar berukuran 1.27 meter dan lebar 60 cm (batu dampar), disebut Batu Pangcalikan Ki Ajar Sukaresi. Di bawah Batu Pangcalikan terdapat sumur (kedalaman $50 \mathrm{~cm}$ ) yang ditutup semen sebagai alas Batu Pangcalikan. Menuju teras pertama ditemukan tiga kolam bersumber pada mata air yang 1 meter dari tangga naik. Jarak ketinggian antara mata air dengan teras sekitar 20 meter.

\subsection{Kabuyutan di Panjalu (Batu Panjang)}

Di Desa Cibeureum, kecamatan Panjalu terdapat situs Batu Panjang. Karena tersebar sejumlah besar menhir besar dan panjang dengan bentuk alami bervariasi dengan kisaran ukuran panjang antara 2,5 m - 3,5 meter, lebarnya antara 50-70 cm dengan bentuk puncak hampir segilima dan agak meruncing. ${ }^{37}$ Bangunan yang diperkirakan sebagai pusat (punden)-nya terletak sekitar 50 meter menuju puncak yang dapat ditempuh melalui jalan setapak di arah barat. Rupa situsnya sendiri berupa punden berundak, sebagian terbesar batu penyusun-nya berserakan namun masih nampak 4 undakan yang membentang utara ke selatan (bagian selatan). Bahan artefak menggunakan batuan kolum (batu-batu tegak) dengan ukuran dan besaran bervariasi antara $100 \mathrm{~cm}-400$. Batuan kolum sekurang-kurangnya ada tiga jenis yakni berpenampang segitiga, segienam dan segiempat. Bentuk berpenampang segitiga bervariasi ukuran $20-35 \mathrm{~cm}$, berpenampang segiempat ukuran sekitar $35-50 \mathrm{~cm}$, bentuk segienam bersisi panjang sekitar $20 \mathrm{~cm}$ dengan diameter $65 \mathrm{~cm}$.

Di lereng utara yang diasumsi bangunan utama ada lima menhir berposisi Tapak

persegi panjang, dengan panjang salah satu sisi sekitar 1.70 meter, lebar 0.30 meter. Batu lain-nya yang jaraknya berdekatan berbentuk hampir empat persegi panjang agak membulat dan datar seperti meja batu, berukuran panjang 1.30 meter. Sebuah batu lagi yang jaraknya agak sedikit berjauhan bentuknya hampir kubus dengan posisi tegak. Tinggi batu sekitar 1.56 meter, tebal 0.50 meter. Bagian dalam bukit, pada suatu cekungan yang terbentuk akibat adanya dua bukit berdampingan terhampar sejumlah besar menhir membentang utara-selatan dengan berbagai ukuran kondisinya terserak tidak beraturan. Bentang cekungan yang mengarah hampir utara-selatan itu menyimpan batu-batu menhir sekitar 140 buah lebih. Batu-batu tersebut memiliki bentuk yang bervariasi, ada yang berbentuk segitiga, segiernpat, segilima, segienam, adapula yang mendekati bentuk kubus. Salah satu batu yang mempunyai ukuran terpanjang adalah 2.44 meter dengan lebar 0.40 meter bentuknya hampir segi lima dengan puncak agak meruncing. Batu pertama berbentuk hampir empat persegi panjang, dengan panjang salah satu sisi sekitar 1.70 meter, lebar 0.30 meter. Batu lainnya yang jaraknya berdekatan berbentuk hampir empat persegi panjang agak membulat dan datar seperti meja batu, berukuran panjang 1.30 meter.Sebuah batu lagi yang jaraknya agak sedikit berjauhan bentuknya hampir kubus dengan posisi tegak. Tinggi batu sekitar 1.56 meter, tebal 0.50 meter.

Berkala Arkeologi Tafiun XXVIEdisi No. 1/Mei 2006 
ing. Batu menhir terletak paling utara sebagai batas bangunan utama (sekarang) berukuran 1 meter berbentuk kolum segiempat, menhir lainnya terletak paling selatan berukuran tinggi $90 \mathrm{~cm}$. Sebaran batu-batu panjang tersebut sebagian besar terkonsentrasi di sekitar lereng utara dan di tengah hutan (sekitar 50 meter ke dalam-selatan), besar kemungkinan bangunan tersebut merupakan teras berundak dengan bentuk mengimposisi mengikuti lahan bukit diakhiri punden di puncaknya. Menurut penduduk setempat, dahulu di punden terdapat lumpang batu yang selalu berisi air, kini hilang dibawa seseorang dari Cirebon (nama dan identitasnya tidak diketahui).

\subsection{Kawasan Gunung Gede Pangrango}

Sejumlah bangunan monumental bercorak tradisi megalitik juga tersebar di kawasan dataran tinggi Sukabumi-Bogor-Cianjur di lingkungan pegunungan GedePangrango. Namun yang dapat diamati 4 bangunan teras berundak yang terkonsentrasi di kecamatan Cisolok: ${ }^{38}$

1. situs Pangguyangan (desa Simarasa - wilayah gunung Datar Jambe dan gunung Batu), terdapat bangunan teras berundak 7 teras dengan dinding yang disusun dari batu batu tegak, pada bagian puncak terdapat punden berbentuk persegi panjang,

2. situs Tugu Gede (desa Cimaja Girang-lereng barat gunung Batu Lawang dan gunung Pangleseran) terdiri dari kompleks utara dan selatan. Kompleks utara berupa menhir-menhir berbagai ukuran; kompleks selatan berupa bangunan teras berundak, di sekitarnya terserak batu bongkah, batu papan, batu dakon, menhir, batu jolang atau (jambangan) dan lumpang batu

3. situs Ci Arca (desa Ciarca) terdapat arca, batu jolang, batu datar, dan menhir. Area bersikap duduk (bersila) dengan tangan melipat di dada (Sunda: sidakep)

4. situs Salak Datar (desa Cimaja) terdapat batu dakon (berlubang tujuh, sejumlah batu seperti digunakan untuk lantai, menhir-menhir kecil dan besar (papan batu disusun berjajar terdiri dari 7 buah) dan batu-batu datar berukuran cukup besar.

Kabupaten Sukabumi merupakan situs ditemukannya prasasti batu Sanghiyang

${ }^{38}$ Ibid. Saringendiyanti (1993:177-183 $)^{39}$ lbid. Saringendiyanti (1993:177-183) 
Tapak di tepi (sungai) Ci Catih - Ci badak, dikeluarkan oleh Sri Maharaja Sri Jayabhupati (932 Saka/1030 Masehi) tentang peresmian aliran sungai sebagai daerah Larangan (daerah suci) Sanghiyang Tpk Mulau bagian hulu, lubuk sungai dan seluruh kandungan isinya tidak boleh mengambil ikan yang hidup di sungai tersebut. Di dalam peta (sungai) CiCatih merupakan sungai cukup besar di wilayah Sukabumi berhulu di gunung Gede-Pangrango mengalir ke hilir bermuara di (sungai) Ci Mandiri kemudian bertemu dengan (sungai) Ci Tarik bermuara di Palabuhan Ratu.

Di kawasan Bogor terdapat insitu prasasti Batutulis (beraksara dan berbahasa Sunda Kuno) merupakan batu peringatan khusus kepada jasa-jasa Sri Baduga Maharaja- dhiraja Ratu Haji di Pakwan Sri Sang Ratu Dewata. Sampai sekarang di sekeliling batu prasasti masih nampak sejumlah batu-batu, ada yang terbaring dan ada yang tegak. Jikalau saja pagar dan cungkup tempat situs prasasti itu tidak ada batu-batu serupa masih tersebar dalam area yang cukup luas, tanpa memperdulikan atau "mencurigai" mengapa di sekeliling prasasti Batutulis berada terserak sejumlah batu besar dengan dalam berbagai ukuran? Ketika Saleh Danasasmita meneliti situs ini memperoleh petunjuk bahwa semula lahan situs Batutulis berbentuk segiempat dikelilingi pagar batu (semacam kompleks) sebagai layaknya kabuyutan di Tatar Pasundan. Dari yang nampak sekarang, kabuyutan Batutulis dapat digambarkan (asli):

1. Memasuki pintu gerbang (selatan) sampai pada halaman terbuka yang tanpa batu-batu, mungkin dahulu ada jalan kecil semacam jalur menuju lingga,

2. Pada halaman kedua ditemukan lima menhir yang terletak dalam satu garis lurus, membujur persis dari timur ke barat. Dua menhir yang terletak di paling timur terpancang pada susunan batu kerakal yang dibentuk persegi panjang (seakanakan kuburan dengan sepasang nisan menurut pengertian "muslim" sekarang), 3. Baris kedua arah timur ditemukan dua batu (dampar?) yang diletakkan berhadapan dengan dua menhir di arah timur (baris pertama) persis di tengah antara dua menhir tersebut; sedangkan batu (dampar?) sebelah barat diletakkan dalam garis antara menhir baris pertama (paling barat) dengan "semacam meja batu" yang berada di belakang prasasti Batutulis. Berada garis lurus ke menhir besar bersegi-6 (Gang Amil) dan batu "Mbah Congkrang" terletak dekat Gang Balekambang. Batu-batu itu terletak garis lurus dengan menhir ketiga menuju 
lingga pusat di sebelah prasasti,

4. Baris ketiga terdapat lingga batu yang tegak dan kokoh sebagai pusat dari seluruh tempat suci (kabuyutan) ini dan disekitarnya terdapat batu-batu lonjong (semacam menhir),

5. Baris keempat terdapat dua batu lainnya. Batu sebelah barat berpenampang segitiga, tetapi alasnya berada di atas dan batu sebelah timur yang bentuknya seperti "meja batu" dilengkapi undakan (semacam tangga) untuk naik ke meja batu tersebut,

6. Tiga batu lainnya berderet di depan prasasti dipasangkan bersama-sama prasasti diantaranya bertanda telapak tangan tanpa jari (seperti aksara "V "), batu yang terletak di tengah berpahatkan sepasang telapak kaki tetapi batu ketiga polos.

Menurut Danasasmita $(1975)^{39}$ batu-batu di sekitar prasasti Batutulis telah ada sejak prasasti ditemukan, karena para peneliti lain hampir selalu terfokus kepada batu bertulis, mereka menganggap batu terserak alami itu seakan tidak istimewa, tidak lebih dari batu biasa. Terdiri dari 5 menhir berderet barat-timur terletak di baris pertama yang dapat lau ditarik garis lurus lalu dihubungkan dengan menhirmenhir lain yang terletak di utara kompleks secara keselunuhan menggambarkan konstelasi benda langit yang disebut rasi kala "Scorpio".

Sejauhmana adanya kepercayaan terhadap kala masyarakat Sunda Pajajaran perlu diteliti seksama, namun pantun-patun kerap mengumandangkan Sunda Buhun pemujaan Kala yang pernah memegang peranan penting. Mungkin Kala harus diterjemahkan sebagai secara infinif merujuk kepada waktu dan era tertentu, ataukah simbol alam itu sendiri? Yang jelas, situs Batutulis, sedikitpun tidak menunjukkan kesan adanya unsur pengaruh Hindu-Budha melainkan corak tradisi megalitik dengan ciri khas penggunaan batu besar dengan ciri khas batu-baru tegak (menhir) berbentuk alami.

\footnotetext{
${ }^{39}$ SaLeh Danasasmita dan Anis Djatisunda, 1986, Kefidupan Masyarakat Kanekes. Bandung: Departemen Pendidikan dan Kebudayaan.

${ }^{40}$ Ten Dam adala fi penefiti pertama yang mencurahkan perfatian terhadap 6atu-6atu tegak sekitar prasasti Batutufis melalui tinjauan sosio-antropologis.
} 
Menurut Ten Dam batu-batu tegak dimaksudkan sebagai lingga, objek terpenting yang dianggap paling suci oleh masyarakat Pajajaran, terutama yang terpancang persis disamping prasastinya yang tiada lain merupakan lambang tanda kekuasaan Sri baduga Maharajadhiraja Sri Sang Ratu Dewata. Ia menyimpulkan prasasti Batutulis diletakkan setelah Sri Baduga meninggal sebagai tanda peringatan kepada atas jasa-jasanya selama memerintah. ${ }^{40}$ Ditambahkan oleh G.P.Rouffaer bahwa lingga batu tersebut tidak hanya berfungsi sebagai kekuasaan sang raja, tetapi juga titik pertemuan kekuatan gaib (divine power) antara raja sebagai Hiyang dengan dunia, pakuning jagat, yang identik dengan peran sang raja sebagai penyelamat dunia.

Bangunan teras berundak di Gede-Pangrango juga ditemukan di kawasan Cianjur. Dalam Laporan Penelitian (Haris Sukendar 1985) diketahui bahwa di kabupaten Cianjur ada 9 situs berupa peninggalan tradisi Megalitik, ia memilahnya dalam 2 katagori yaitu tujuh situs sebagai peninggalan megalitik (Gunung Padang, Pasir Pogor, Bukit Tongtu, Bukit Kasur, Gunung Putri, Lemah Duhur, Pasir Manggis); dua situs sebagai peninggalan tradisi megalitik (Pasir Gada dan Ciranjang). Namun tidak disertai alasan pemilahannya seperi halnya Saringendiyanti (1993) tatkala mengkatagorikan bangunan-bangunan corak tradisi megalitik di kawasan ini ke dalam situs-situs percontoh ambang keraguan.

Terlepas dari “ambang keraguan", bangunan bangunan tersebut nyata-nampak tegas hadir di permukaan. Sebab pada dasarnya, manusia sebagai mahluk berakal (animal simbolicum) selalu memiliki dan melandasi dirinya dengan akal sehat dalam membuat segala sesuatu bagi kebutuhan kebudayaannya. Pada Hakekatnya, setiap benda budaya mengandung gagasan penciptanya merupakan hak mutlak kekayaan pengalaman bathin pelaku budaya.

\section{Tatanan Kosmis sebagai Lambang Kabuyutan Sunda Wiwitan}

Tataletak situs-situs di kawasan Lebak berada di dalam satuan ruang geografis dengan morphologis lembah, gunung dan sungai suatu penempatan lahan dengan memilih bukit, dataran tinggi (atau hulu sungai) serta ketepatannya dengan pertemuan sungai besar. Media artefak-artefaknya batu besar, tidak dibentuk secara khusus 
atau dimodifikasi tetapi sesuai kondisi alaminya (mengimposisi kepada alam). Perilaku yang mencerminkan kearifan dengan tidak merusak lahan, lingkungan dan kandungan sumberdaya, melainkan melestari-kan segala sesuatu yang telah tersedia dan terkandung oleh ekosistem (alam)nya. Sikap budaya yang direduksi oleh tradisi mengimposisi kepada alam dengan tanpa merubah apalagi merusak apa yang tersedia pada alam tersebut masih diperta-hankan secara ketat oleh salah satu kelompok masyarakat yang kini ada di kawasan Lebak, yakni Kanekes. Tidak heran masyarakat Kanekes sangat tegas menolak tatkala dituduh keturunan pelarian Pajajaran, juga terang-terangan menolak disebut Baduy (istilah semenamena kolonial Belanda berarti "liar - tidak berbudaya").

Kenyataan membuktikan di kawasan Lebak terdapat sejumlah besar warisan budaya Sunda sejak Tarumanagara, jauh lebih tua mengawali Sunda-Pajajaran. ${ }^{4 l}$ orientasi punden situs Kawali (gunung sawal0 dan situs Susuru (Pasir Susuru) mengarah barat laut dimana terletak hulu (sungai) Ci Muntur Ke arah paling hilir DAS Ci Muntur bertemu dengan Ci Leueur adalah situs Susuru dan pada perjalanan akhir Ci Muntur setelah bertemu dengan Ci Tanduy bermuara di Segara Anakan melaju ke laut selatan di Karangkamulyan.

Diantara sejumlah Kabuyutan di Tatar Sunda, mungkin situs Kawali satu-satunya yang secara langsung dilengkapi dengan prasasti yang isinya konsep ajaran Sunda Wiwitan dilengkapi cara-caranya. Meski tidak bertanggal namun atas dasar perbandingan dengan karyasastra Sewa Ka Darma bertanggal Nanu Namas Haba Jaja (1021=1099 Masehi) maka Sunda Wiwitan berlangsung di Kawali (Ciamis) pada periode tersebut. Itu sebabnya situs Kawali, Kawali dan situs Susuru mengindikasikan teras atau punden berundak dan memilih lokasi lereng gunung disertai bentuk yang mengikuti bentang alam makin keatas makin meninggi tampaknya dilandasi oleh pertimbangan magis dan praktis. Mengacu kepada letak geografis dan kondisi fisiografis menempati lahan bukit dengan alur sungai berhulu ke Gunung Sawal dan Gunung Cijulang sebagai Kabuyutan tertinggi di paling hulu (Panjalu).

Dari sejumlah fakta yang ada, sejak awal morphologis kawasan Bogor- 
Sukabumi (termasuk Cianjur) di kawasan lingkungan Gede-Pangrango di masa lalu tentu tidak dipilah sebagai kawasan geografis sekarang. Melainkan kesatuan rangkaian lempeng pegunungan zona tengah. Masuk akal pula jikalau BogorSukabumi dan Cianjur pada masa lampau tidak dipisah menurut geografis kabupaten (OtoDa) sekarang, tetapi sesuai tatanan dan kondisi lingkungan kekuasaan suatu kerajaan (hierarkis tertinggi). Maka penempatan bangunan-bangunan bercorak tradisi Megalitik dengan memilih kawasan Bogor-Sukabumi - Cianjur sangat beralasan. Secara morphologis Sukabumi terletak di lereng selatan gunung GedePangrango, Bogor di lereng utara gunung Gede-Pangrango, dan Cianjur di lereng timur gunung Gede-Pangrango. Mungkinkah warisan budaya berupa monumen yang bercorak tradisi megalitik tersebut memilih kawasan ini karena memang sengaja berpusat ke gunung Gede-Pangrango.

Di dalam peta tampak Gede-Pangrango" seakan gunung kembar dan tidak terpisah", bahkan karyasastra Sunda Kuno Bujangga Manik pernah menuturkan .gunung Gede adalah kabuyutan Pakwan-Pajajaran. Ia tidak menyebut nama lain walau ada gunung-gunung lain di sekelilingnya. Dalam peta gunung GedePangrango berada dalam tatanan lempengan pegunungan Zona Tengah dengan gunung Salak dan gunung Halimun di barat dan gunung TangkubanparahuBukitnunggul dan gunung Ciremai di arah timur. Lempengan pegunungan Zona Tengah berhadapan dengan lempeng pegunungan Zona Selatan berakhir di Samudra Indonesia (laut selatan). Besar kemungkinan di masa lalu gunung Gede-Pangrango lebih dikenal disebut gunung Gede saja sebagai pusat kabuyutan kerajaan Sunda. Di kawasan ini pula terkonsentrasi bangunan-bangunan monumental keagamaan yang bercorak tradisi megalitik.

Pendirian suatu bangunan apalagi untuk kepentingan sesuatu yang suci, secara langsung terkait kepada dua aspek pokok yang dipakai sebagai patokan yaitu aspek teknis dan aspek keagamaan. Aspek teknis adalah segala sesuatu yang

\footnotetext{
\$l Sekali lagi persepsi keliru dilontarkan oleh para sarjana (etik) bahwa masyarakat Kanekes dituduh lari ke pegunungan Kendeng antara lain dihubungkan dengan gejala mesianik, tatkala inovasi Islam tiba di Jawa Barat. Padahal alasannya jelas bahwa masyarakat ini memang telahada dan menghuni di kawasan ini, tercermin dari pengakuan dirinya sebagai Jafi Sunda atau Sunda Wiwitar.
} 
berkaitan dengan perencanaan atau pendirian bangunan suci, baik teknis konstruksi (bahan bangunan, cara pembuatan, gaya, teknis arsitektur) dan segi keindahan; aspek keagamaan dipakai sebagai bahan pertimbangan dan perencanaan bangunan suci selaras kebutuhan dan fungsinya sebagai sarana untuk merealisasikan upacara keagamaan. ${ }^{42}$

Tentu saja, sangat tidak masuk akal apabila Urang Sunda mendirikan sekian banyak teras berundak dikonsentrasikan di dataran -dataran (ter)tinggi, bukit atau gunung dengan tanpa maksud dan tujuan tertentu. Salah satu contoh nyata adalah bangunan-bangunan Kabuyutan di wilayah Ciamis dan sekitarnya yang disebut Priangan Timur terletak di kawasan volkanik merupakan kompleks gunungapi tua terdiri dari Gunung Sawal (1764 m), Gunung Cakrabuana (1724 m) yang terletak disebelah baratlaut Gunung Sawal. Terletak di sebelah barat terhampar jajaran pengunungan yang membujur utara ke selatan meliputi Gunung Sadakeling, Gunung Baturohang, dan yang tertinggi serta tetap aktif adalah Gunung Galunggung (700$2000 \mathrm{~m}$ ). Di selatan Gunung Galunggung terdapat Perbukitan Sepuluhribu (bukitbukit kecil; Sunda: Pasir), jumlah sebenarnya 3600 bukit berketinggian rata-rata $5-50 \mathrm{~m}$ terlampar mulai dinding yang berbentuk ladam dari Gunung Galunggung (Kabuyutan Galunggung) meluas ke tenggara ke Manonjaya (Tasikmalaya).

Gunung Sawal adalah gunungapi strato yang telah lama padam dan terkikis sangat dalam yang diperkirakan berumur Plio-Pliosen, masa pernah berlangsungnya letusan Gunung Sawal yang dahsyat sehingga membentuk kaldera sangat besar pada bagian puncaknya serta memunculkan puncak-puncak baru yaitu Gunung Kawah, Gunung Sinambat, Gunung Manglayang dan Gunung Sawal sekarang (Kabuyutan Kawali, Susuru, dan Gunungpadang).

Di timurlaut Gunung Sawal terletak Gunung Cijulang yangmemiliki haluan nyata berpematang tenggara-baratlaut dimana terdapat Kabuyutan BatupanjangPanjalu. Kabuyutan Panjalu terletak di sebelah barat Gunung Cijulang, menempati punggungan (Sunda:Geger) Gunung Cijulang. Antara Gunung Sawal dan Gunung Cijulang terdapat dataran memanjang yang litologinya dari gunungapi tua Gunung Sawal (Plio-Pliosen), ketika terlampar mencapai hingga Gunung Cijulang 
(Kabuyutan Batupanjang). Di punggung pegunungan Cijulang pada dataran yang agak rendah terdapat bukit-bukit kecil (Sunda: Pasir) diantaranya Pasir Lebak, Pasir Naja, dan Pasir Garu. Juga mengalir sungai-sungai besar dan utama yakni Ci Tanduy, Ci Muntur dan Ci Julang. Ci Tanduy berhulu di Gunung Cakrabuana membelah kawasan pegunungan sebelah barat Gunung Sawal dan Gunung Cakrabuana, mengalir mengelilingi Gunung Sawal bertemu anak-anak sungai yang berhulu ke Gunung Sawal dan Gunung Cijulang. Begitupun Ci Muntur mengalir diantara Gunung Sawal dan Gunung Cijulang (timurlaut) berhulu ke punggung barat Gunung Cijulang dengan arah aliran barat laut-tenggara. Sedangkan Ci Julang berhulu di timurlaut Gunung Cijulang mengalir arah tenggara bertemu dengan $\mathrm{Ci}$ Muntur di daerah selacai melanjutkan perjalanannya melewati Karangka- mulyan (Cikoneng) bertemu Ci Tanduy selanjutnya bermuara ke Segara Anakan (Pantai Selatan Jawa Barat). Das Ci Muntur adalah terletaknya situs Kawali (lereng timur Gunung Sawal) dan situs Susuru (tenggara) di bagian lebih ke hulu (Gunung Cijulang) terletak situs Panjalu (Batu Panjang). Jikau ditarik garis lurus maka situs Panjalu Kawali dan Susuru berada tepat satu garis lurus arah baratlaut-tenggara pada keletakan $150^{\circ}$.

Penempatan bangunan pola hulu-hilir ini mengingatkan kepada keterangan dalam kropak 630 (Sanghiyang Siksa Kanda Ng Karesian) dan kropak 632 (Kabuyutan ti Ciburuy) yang menguraikan tentang kosmologi masyarakat Sunda yakni konsep "tritangtu di bumi, bayu pinaka prebu, sabda pinaka rama, hedap pinaka resi ya kangken pineguh ning bwana ngaranna". Konsep yang sama hingga kini tetap menjadi acuan dan diberlakukan ketat sebagai landasan kehidupan dalam bentuk tatanan ruang (mandala) masyarakat Kanekes di Banten Selatan, dengan latar kepercayaan Sunda Wiwitan. Dimana setiap ruang disebut tangtu yang seluruhnya berjumlah tiga (tlutangtu) masing-masing diketuai Puun berpusat kepada rama (tangtu Cikeusik/puun rama); resi (tangtu Cikartawanal puun pandita) dan prabu (tangtu Cibeo/puun ponggawa). Puun Cikeusik adalah puun tertua tanpa memandang usia karenanya terletak di paling dalam atas hulu

\footnotetext{
42 Periksa Parmono Atmadi, Beberapa Patokan Perancangan Bangunan Candi: Suatu Penelitian Melalui Ungkapan Bangunan Pada relief Candi Borobudur, Pelita Borobudur, Jakarta: Proyek Pemugaran Candi Borobudur , 1979: 2.
} 
sungai berurut ke arah hilir sebagai kesatuan atau Tritunggal yang tidak terpisahkan. Maka dalam tatanan ruang Kabuyutan Ciamis yang tertua haruslah situs Panjalu (Batu Panjang) merupakan hulu seluruh induk sungai mengalir di kawasan Ciamis.

Tatar Sunda "Ki Sunda" disebut Parahiyangan sangat mencerminkan kepada tatanan alamnya. Berkaitan kepada Sunda Yang Asal merujuk kepada tatanan historis awal terciptanya Tatar Sunda. Menurut para Pakar, Sunda berasal dari Cuddha artinya putih, bersih, cemerlang yang terbentuk secvara geologis pada 2 juta tahun yang lampau, oleh serangkaian aktivitas volkanik antara Bandung Cimahi - Manglayang (Priangan Timur) bergeser ke utara sehingga membentuk gunungapi purba Gunung Sunda mencapai ketinggian 300 meter (dpl). Ketika gunung tersebut meletus membentuk dataran Sunda yang ada sekarang. Dari peristiwa ini ditemukan berbagai artefak ditutupi oleh abu kasar (lapilli tuff) sezaman pada hampir seluruh Tatar Sunda. Temuan obsidian dan kalsedon berupa serpihan (chips), batu bulat andesit (chopper) dan tulang belulang binatang, menunjuk sisa aktivitas manusia purba zaman mikrolithicum sebagai Karuhun Ki Sunda.

Berdasarkan peta fisiografi Jawa Barat oleh van Bemmelen (1949) situs gunung Susuru dan sekitarnya terletak pada Zona Bandung, satu-satunya zona murni fisiografi dan secara geologi tidak mudah untuk dibedakan dengan zona Bogor. Zona Bandung sebagian terbesar tertutup endapan hasil gunungapi Resen dengan singkapan endapan Tersier di beberapa tempat. Pun situs Susuru dan sekitarnya berada pada persebaran satuan batuan hasil gunungapi tua namun dengan bentang alam (geomorphologis) agak berbeda. Jika situs Kawali menempati bentang lahan dataran tinggi bergelombang sedangkan situs Susuru berada pada bentang lahan dataran rendah yang bergelombang (van Bemmelen 1949; Budhisutrisna T. 1987).

Kabuyutan kaitannya dengan Ideologi Urang Sunda yang disebut Sunda Wiwitan? Kabuyutan berasal dari [ka]-buyut-[an] dengan kata dasar buyut kerap diucapkan puyut atau menghilangkan fonem awal menjadi $u y u t$, artinya pupunden, segala sesuatu yang paling dihormati, ujudnya dapat berupa manusia, tempat (lahan, lokasi, tata letak) dan benda-benda lain yang dipandang suci seperti 
keris, pohon (tua), gunung, bangunan dan tempat pertapaan. ${ }^{43}$ Kata buyut sebenarnya berakar dari but dan sering diberi kata sandang hormat $[\mathrm{ra}]$ — rabutra [m]but diletakkan di depan kata sebagai istilah menyebut tempat-tempat suci di Jawa dan Bali (rabut Carat, rabut Macan Petak, rabut Girah).

Kabuyutan di Tatar Pasundan juga berasal dari but $>$ buyut yang diberi awalan [ke] dan akhiran [an] - kata jadian berimbuhan yang fungsinya setara dengan [ke]-[an] dalam tata bahasa Indonesia untuk menyatakan tempat atau sesuatu [benda] yang bersifat abstrak. Sepadan dengan kata dasarnya istilah kabuyutan merujuk kepada segala sesuatu yang bersifat suci atau dianggap suci termasuk juga bangunan suci atau pusat upacara keagamaan dengan seluruh aspek dan perangkatnya. Terdiri dari dua kata dasar yaitu Sunda dan Wiwitan. Agaknya istilah Sunda tidak perlu dijelaskan lagi karena mengacu kepada subjek yakni individu/masyarakat Sunda. Yang masih sangat perlu dijelaskan adalah wiwitan, berasal dari kata dasar [wiwit] dan akhiran [an], wiwitan adalah kata jadian .dengan sufik [-an]. Wiwitan artinya asal, pokok, jati sepadan dengan Jati [Sunda] yang dituturkan dalam karyasastra Carita Parahiyangan; wiwit juga dapat dibaca bibit artinya semaian atau benih yang dapat diterapkan ke dalam berbagai keadaan, kondisi atau benda. Sampai kini Urang Sunda mengenal istilah bibit-buit (kata benda) artinya leluhur suatu individu atau kelompok masyarakat (asal keturunan).

Urang Sunda menyebut leluhurnya karuhun atau buyut $>$ buyut Sunda sepadan dengan Wiwitan Sunda (Sunda Wiwitan) atau Jati Sunda walaupun letaknya dapat dibalik tetapi fungsi maupun pengertiannya tetap tidak dapat dan tidak bisa berubah sebagai kata benda, akhiran [-an] adalah kata penghubung [yang-]. ${ }^{44}$ Sunda Wiwitan merupakan bentuk kepercayaan atau keyakinan dengan kata awal wiwit(-an) berkait langsung dengan Sunda yaitu keyakinan yang berpatokan kepada yang telah ada sejak awal manusia Sunda ada di bumi yakni leluhurnya (Hiyang), selanjutnya ditahtakan di suatu kabuyutan. ${ }^{45}$

Istilah kabuyutan ditetapkan karena istilah ini dipandang mampu menyampaikan dan mengkomunikasikan kebenaran pengalamannya. Jikalau "terasa tidak lazim", berbeda atau bergeser dari kebiasaan, persoalannya terletak pada bagaimana 
kekayaan budaya dibahasakan oleh si pelaku budaya. Karena bahasa bukan semata istilah tetapi mediator centrum, dimana perbedaan dan pegeseran senantiasa berkait kepada realitas kekayaan budaya dan kebenaran dalam kesatuannya sebagai salah etnis Nusantara. Dapat dikatakan bahwa bahasa suatu individu atau kelompok masyarakat adalah realitas yang diyakini sebagai kebenaran.

Ayatrohaedi menyatakan bahwa salah satu "benang merah" yang dapat memberi keterangan tentang pesan data kebudayaan Urang Sunda adalah cerita tutur atau sejarah lisan yang tumbuh dikalangan para pemangkunya. ${ }^{46}$

Disuratkan dalam karyasastra Carita Parahiyangan:47

"setia kepada kebiasaan dan keaslian leluhur, oleh karena itu tidak akan kedatangan oleh musuh gangal (kasar) dan musuh alit (halus). Sejahteralah di utara, selatan, barat dan timur, karena perasaan yang tenteram. Yang tidak tenteram hanyalah rumah tangga orang banyak (urang reya) karena melanggar sanghiyang siksa"

Acuan kehidupan berpatokan kepada ajaran warisan leluhur tetap tercermin dalam kehidupan Urang Kanekes (Baduy) yang tegas mengakui bahwa awal kelahiran mandala Sunda Wiwitan atau Sunda Asli (Jati Sunda) diawali di tanah Kanekes yang kini lestari menghuni dataran tinggi parahiyangan, rangkaian pegunungan berawal di Ujung Kulon, mulai dari Pegunungan Kendeng (Lebak) hingga Pegunungan Ijen (Banyuwangi- Jawa Timur) berbatas Samudra Indonesia. $^{48}$

Kondisi Fisiografis Tatar Sunda terdiri deretan pegunungan tinggi diantaranya masih banyak yang aktif, kawasan barat terhampar deretan pegunungan Gagak-

\footnotetext{
${ }^{43}$ Poerbatjaraka (1992), Agastya di Nusantara. Seri Terjemahan KITLV-LIPI. Ed. 1.Cet.1.Jakarta: Yayasan Obor Indonesia. Judul Asli Poerbatjaraka (Lesya), Agastya in den Archipel. N.V.Boekhandel en Drukkerij voorh.E.J.Brill - Leiden 1926.

$د$ Masyarakat Sunda khususnya di Ciamis (Priangan Timur) tetap memakai kata buyut untuk menyebut segala sesuatu yang dipandang suci, tabu atau pamali.

${ }^{15}$ Masyarakat Sunda di Ciamis menyebut yang berusia tua sekali dengan "bercanda" dengan ungkapan tereh ngahiyang. dan menyebut yang sudah meninggal "anggeus ngahiyang" atau "geus hilang".
} 
Salak-Pangrango-Gede; kawasan utara terhampar deretan pegunungan Burangrang-Tangkuban-parahu-Bukitnunggul-Calangcang-Cakrabuana; kawasan selatan terhampar pegunungan Kendeng-Patuha-Gunungtilu- MalabarPapandayan-Cikuray; dan kawasan timur deretan pegunungan GunturMandalawangi ${ }^{49}$ Inilah dataran tinggi Parahiyangan Urang Sunda sebagai tahta tempat berkumpulnya para hiyang (Kabuyutan) simbol persemayaman leluhur (buyut) dan segala sesuatu yang asal (wiwitan) yang kemudian presentasikan kepada bangunan suci dengan perangkat keyakinannya (religious background) mencakup pengetahuan kehidupan Urang Sunda yang dilihat, diraba, dan dinikmati dan tempat mereka kelak pulang.

Gunung-gunung tersebut adalah Kabuyutan, simbol kosmis Urang Sunda, tatanan kosmis merealisasikan keyakinan dimana gunung menjadi inti kosmos (jagatsemesta) di dunia. Masuk akal jikalau Urang Kanekes meyakini Sunda teh $n u$ Wiwitan (Sundalah yang tertua) dimana Pegunungan Kendeng adalah tulang punggung Pulau Jawa, kepala-nya (Sanghiyang Sirah) kawasan Lebak, kakinya .(Sanghiyang Dampal) di Banyuwangi, pusar (Sunda: Bujal)nya di Kosala. Kawasan Lebak sendiri adalah jajantung Alam, dan Ujung Genteng adalah Sanghiyang Beuheung (Leher). Jikalau tulang punggung dirusak maka hancurlah Pulau Jawa, karena itu tugas manusia adalah mulasara (memelihara) alam tempat mereka hidup..$^{50}$

Kepribadian yang berintikan keyakinan Sunda Wiwitan terhadap leluhur atau karuhun yang disebut Hiyang, unsur tertinggi pemujaan yang menyebabkan Urang Sunda ada di Buana (dunia) ini. Keyakinan yang mengingatkan kepada kepercayaan

\footnotetext{
46 Peringatan ini disampaikan "Mang Ayat" secara lansung kepada penulis dalam beberapa kali kesempatan pertemuan seminar tentang Sunda.

${ }^{47}$ Atja (1968), Tjarita Parahiyangan, Titilar Karuhun Urang Sunda Abad Ka 16 Masehi. Bandung: Yayasan Nusa Larang.

${ }^{48}$ Walter J.Ong (1967) mengemukakan bahwa di dalam suatu kebudayaan lisan kita hanya bisa menanyakan sesuatu, tetapi kita tidak bisa mengecek atau menurut apapun. Tetapi tidak dapat diabaikan bahwa masa lampau kebudayaan lisan adalah masa kininya, sebagaimana tersiman di dalam bahasanya dan institusi sosialnya yang ada sekarang. Jadi ber-beda dengan pengkajian sejarah modem dimana peneliti bisa mengambil jarak, dalam arti mengadakan abstraksi tentang masa lampau suatu suatu kebudayaan berdasarkan catatan atau naskah tertulis seperti sejarah lisan tidak bisa melepaska kekinian suatu kebudayaan lisan dalam usaha untuk membuat masa lampau kebudayaan tersebut. Pada dasamya baik yang menyangkut sejarah modem yang berlandaskan sumber tertulid maupun sejarah lisan hanya berdasarkan laporan lisan masa kini, lampau dan kini berbaur sebab masa lampau hanya memiliki makna dalam konteks pengertian masa kini. Sebaliknya
} 
yang hidup dan berkembang pada masyarakat perundagian. Dimana gunung dipandang sebagai pusat paling sakral, tahta persemayaman roh suci (parahiyangan). ${ }^{51}$ Sebagian besar denah bangunan sucinya mengambil bentuk teras berundak dilengkapi punden di suatu gunung tertinggi (konsentris). Unsur yang menonjol di sini adalah pemujaan kepada nenek moyang yang menghadirkan tata kehidupan teratur dengan menjaga agar tingkah laku setiap anggota masyarakat di dunia sesuai tuntunan hidup di alam arwah. Begitu pun keberhasilan segala usaha ditentukan oleh adanya kekuatan supranatural, karena itu setiap usaha disertai upacara, ditujukan untuk memperoleh restu dari arwah nenek moyang. ${ }^{52}$

Dalam konsep kepercayaan itu berlaku suatu anggapan bahywa kematian seseorang tidak membawa perubahan esensial kedudukan dan sifat seseorang. Seseorang meninggal mempunyai kedudukan yang sama seperti ketika masih hidup, maka roh itu tidaklah lenyap melainkan hidup abadi di alam arwah, sehingga roh seseorang yang meninggal dunia (leluhur, nenekmoyang) tetap dapat menjalin hubungan baik dengan yang hidup di dunia. Untuk menjalin hubungan roh nenek moyang (leluhur) (keluarga dan masyarakat), didirikanlah bangunan-bangunan atau wujud-wujud tertentu (simbol) yang dikenal sebagai bangunan megalitik, dengan harapan agar roh leluhur memberi kesejahteraan, kesuburan kepada pendiri bangunan dan kepada masyarakat. ${ }^{53}$

Roh leluhur (roh nenek moyang) dipercaya bersemayam di puncak gunung maka gunung bagi masyarakat perundagian sangat berperan penting khususnya sebagai tempat suci (persemayaman) juga sumberdaya alam, dan (simbol) sumber kesuburan. Dari gunung air keluar dan memberi kehidupan pada semua mahluk di dunia. Air yang mengalir dan berasal dari hulu (gunung) esensi pensucian dan penyuburan, simbol arus kehidupan yang diarungi dan direalisasikan, atau media untuk menyeberangi dan mencapai tujuan hingga ke pusat atau prinsip tertinggi yang dilambangkan bertahta di puncak gunung. Itulah sebabnya bangunan megalitik

\footnotetext{
masa kini memiliki makna karena berpijak pada masa lampau. Hakekatnya semua itu terjadi karena kesadaran manusia tidak memisah-misahkan atau memilah-milahkan yang lampau dan yang kini, keduaduanya ada dan menyatu dalam kesadaran. Teks lisan umunnya diperlakukan dan dianggap folklore sebagai bagian dari sastra lisan serta
} 
umumnya didirikan di puncak gunung, atau diarahkan ke gunung. Lingkungan pegunungan, pilihan dan penempatan tepat pada pertemuan sungai bukan sekedar berdasarkan faktor kesuburan belaka, tetapi konsep memahami bahwa pertemuan aliran (air) sungai merupakan simbol bertemunya halk-hal yang suci sekaligus menghubungkan kehidupan dari dan kepada hulu yang sama. Konsep pemujaan yang menganggap bahwa tempat tinggi merupakan tempat suci persemayaman leluhur, landasan keyakinan masyarakat di Nusantara sejak awal. Inilah yang tetap dilestarikan Urang Sunda. sampai sekarang khususnya yang nampak di Kanekes.

\section{Penutup}

Betapapun luas perbedaan kondisi Urang Sunda sekarang namun patut dicermati bahwa kepercayaan bagi penganutnya disebut agama. ${ }^{54}$ Secara nirsadar ${ }^{55}$, agama Urang berkaitan dengan dimensi mental (mentalitas), di satu sisi mentalitas Urang Sunda yang tercermin dalam tradisi lisan (tutur) sebagai - upaya pelestarian pengalaman masa lampau(warisan leluhur), di sisi lain mentalitas Urang Sunda yang didasari sifat fleksibel dalam menyikapi berbagai macam aliran yang berkembang di lingkungannya, menerima berbagai kelompok keagamaan selama tidak menyimpang terlalu jauh (dalam) dari tradisi Kasundaan. ${ }^{56}$ Sebab memang, pada dasarnya dimensi esoteris agama atau kepercayaan sebagaiman terjadi dalam suatu kebudayaan tidaklah berdiri sendiri, tetapi berkaitan dengan dimensi-dimemsi di luar dirinya. Selain dibentuk oleh subtansi ajaran (asli-asal) juga dipengaruhi struktur sosial, tempat keyakinan yang dimanifestasikan pemeluknya.

merupakan perlambangan nyata dan benar dari pengalaman sosial suatu kwbudayaan lisan. Disamping itu folklore lahir bukan semata untuk tujuan artistik melainkan berdasarkan tujuan ritual dalam arti yang seluasluasnya. Di sinilah peran peneliti harus memperhitungkan perspektif dan pandangan suatu kebudayaan lisan tentang teks-teks yang diturun-turunkan dan dipelihara sebagai warisan kebudayaan sebab bagi masyarakat yang memiliki teks tersebut, ia benar-benar nyata benar.

${ }^{2}$ Disampaikan langsung kepada Penulis oleh ProI.Dr. Yahdi Zaim, Dosen Senior Geologi dari Intitut Teknologi Bandung

${ }^{50}$ Keterangfan ini disampai oleh Ayah Dainah (47 tahun) Jaro Pamarentah dari Kampung Balingning (Kanekes - Baduy Luar) dan Ayah Mursid (35 tahun) Jaro Ciheo (Kanekes - Baduy Jero). Betapaoun mereka tidak mengenal langsung pendidikan formal namun kearifan mereka mengenal alam layak diperhitungkan.

Berkafa Arkeologi Tahun XXWI Edisi No. 1/Mei 2006 
Dalam konteks tertentu, agama melakukan adaptasi dan legitimasi (fungsi) terhadap proses perubahan yang terjadi disekitarnya. ${ }^{57}$ Begitupun Urang Sunda menjalan-kan keagamaannya (keyakinan, kepercayaan) memang nampak kecenderungan tidak menonjolkan formalisme keyakinan atas kepercayaannya tapi lebih memahami substansi agama yang diwujukannya ke dalam kehidupan sehari-hari sebagai realisasi "nanjeur na juritan" atau sebagai tapa dina mandala, yakni "ngeumbing kana agama nyarande kana pikukuh keur nyambung jeung karuhun di Kabuyutan Sunda nu Wiwitan". Tercermin di dalam kehidupan nyata Urang Kanekes:

“ Mun kami mah kumaha ceuk kolot bae, menta dipangdeukeutkeun pituduh, menta panglindungna bae, hayang cageur, bageur, ulah deukeut teuing kana panyakit, kitu bae. Di dieu oge disebutna Buana panca Tengah, aya agama aya pikukuh. Ngan lamun di ditu aya Rasul, Mulud, Ekah, Kurban, di dieu mah aya Ngawalu, Ngalanjakan, Kapundayan, ti Karuhun kami, eta bae. Kami mah lain nyaho tina gambar tapi ti kabar, jadi di jero hate ayana" 58

(= Jika kita bagaimana benar menurut orang-orang tua saja, memohon tidak menyimpang dari petunjuk, mohon lindungannya agar selalu sadar dan bersih hati, dan tidak terpengaruh hal-hal yang buruk, itulah adanya. Kita ini sama-sama berada dan hidup di dunia (alam) nyata memiliki keyakinan dan ketentuan adat istiadat. Hanya saja kalau di situ percaya kepada Rasul, Ekah dan Kurban, kami memiliki Ngawalu, Ngalanjakan, Kapundayan dari Karuhun kami sendiri. itulah adanya. Semua yang kami tahu bukan karena kami belajar formal, tetapi membaca kehidupan ini dan pengetahuan itu tersimpah di dalam bathin)

\footnotetext{
5) Dalam prasasti Kebantenan lempeng IV recto(tanpa angka tahun) gunung tersuci itu disebut Gunung Samaya, bukan nama gunung sesungguhnya melainlkan gunung yang menjadi persemayaman leluhur (Hiyang), yang dimaksud adalah seluruh dataran tinggi parahiyangan.

52 R.P. Soejono (1977) Sejarah Nasional Indonesia, I. Jakarta: balai Pustaka.

${ }^{33}$ Sumijati Atmosudiro (1981), Bangunan Megalitik Salah Satu Serminan Solidaritas Masa Perundagian,

Berkala Arkeologi. B. Ark. II. (1). Balai Arkeologi Yogyakarta, Maret 1981: 36-41.

${ }^{54}$ Ansal Bakhtiar, Filsafat Agama, Logos (Wacana Ilmu dan Pemikiran), 1999.

5s Istilah nirsadar diakai oleh Dr.Shri Heddy Ahjmsa Putra untuk menyebut kesadaran yang tidak disadari yang tersimpan dibawah alam sadar
} 
Pemahaman konsep kehidupan seperti yang diungkapkan karyasastra Sunda Kuno Keropak 630 dan Keropak 632 "mana kreta na buwana, mana hayu ikang jagat kena twah ning janma kapahayu" (maka sejahteralah dunia, maka bahagialah seisi jagat semesta apabila perbuatan manusia penuh kebaikan).

Konsep Kabuyutan dan Sunda Wiwitan bukan sekedar keyakinan yang hanya dipahami dan diwujudkan ke dalam bentuk tatanan idiofak, tetapi dalam kehidupan sehari-hari dalam menata lingkungan hunian. Inti dari hunian mandala Kanekes merujuk dari lembah ke arah puncak dengan mengikuti alur sungai dari hilir ke hulu dimana terletak gunung. Demikianlah Kampung Ciboleger yang terletak paling hilir yang disebut Baduy Luar, bukan merupakan "tempat pembuangan" orangorang yang terhukum tetapi lebih berfungsi sebagai pintu gerbang masuk ke bagian hulu (Girang) yang merupakan hunian kaum elit "Tlu Tangtu" disebut Baduy Jero (kaum kajeroan) meliputi Kampung Cibeo (Tangtu Parahiyang) diketuai Puun Prabu, Kampung Cikartawana (Tangtu Kadu Kujang) diketuai Puun Resi (Pandita) dan yang paling suci adalah Kampung Cikeusik (Tangtu Pada Ageung) diketuai Puun Rama, letaknya di lahan tertinggi pada hulu aliran (sungai) Ci Ujung (yang tersuci). Hunian maupun lingkungan sekitarnya adalah yang dipertapakan dan diperlakukan hati-hati oleh penghuninya.

Di dalam memanfaatkan lingkungan, mereka lebih mengutamakan konservasi dari pada eksploitasi, kalaupun ada yang harus diambil (Sunda:diala) atau dirubah dilakukan sangat terbatas (minimal) sesuai batas keperluan saja. Sebab semua yang di buana panca tengah (dunia) berasal Turun Ti Nu Rahayu ( turun dari yang baik) maka dalam keadaan rahayu pula harus kembali. Inilah inti kepercayaan Urang Sunda memelihara dan melestarikan segala yang telah ada sejak semula, mereka menghomati dengan tidak merubah apapun termasuk bentuk teras paling

\footnotetext{
${ }^{56}$ Dadang Kahmad, Agama Islam dan Budaya Sunda, SubTema Bidang Kajian agama dan Kepercayaan, dalam Ajip Roside et.al. (editor), Konferensi Internasional Budauya Sunda (KIBS), Jilid I. Prosiding. Yayasan Kebudayaan Rancage. 2006 halaman 321-329.

${ }^{37}$ David Trueblood, Philosophy of Religion. Diterjemahkan dan disusun kembali oleh Prof.Dr. H.M.Rasjidi dengan judul Filsafat Agama. Jakarta: Bulan Bintang. Tahun 1990. Cetakan Kedelapan.' Tiwi Purwitasati, Kultus Arca Domas Dalam Hubyngannya Dengan Pelestarian Hutan (Studi Tentang Kearifan Ekologis Komunitas Baduy Kompol, Desa Sangkanwangi, Leuwidamar, Lebak, Jawa Barat), Skripsi Jurusan Antropolugi, Fakultas Ilmu Sosial dan Ilmu Politik Universitas Padjadjaran Bandung, 1998.
} 
berundak (corak tradisi megalitik) yang mengimposisi kepada gunung dan segala isinya tetap menjadi acuan hingga ke periode yang disebut Hindu-Budha. Jelas, Kabuyutan memiliki tujuan dan kepentingan tertentu sebagai milik hakiki masyarakat Sunda yang tercipta dan dicipta atas dasar kesepakatan pengalaman kebudayaan sekurang-kurangnya kala bukti tertulis ditemukan di Tatar Sunda abad IV-V Masehi (Tarumanagara) dan seterusnya menjadi acuan kehidupan masa kemudian.

Apa yang telah diuraikan mungkin masih terlalu "pagi" tetapi yang jelas bahwa Urang Sunda pada masa Hindu-Budha yang ditandai dengan maraknya pengaruh luar kala itu, memiliki kemampuan dan kecerdasan di dalam menata kehidupan. Suatu strategi kehidupan menyesuaikan diri dengan lingkungannya. Diketahui bahwa peninggalan dari akhir masa prasejarah di Tatar Sunda tidak terdapat petunjuk adanya pengaruh dari luar. Kebiasaan membuat punden berundak telah berlangsung terus (seperti juga budaya Austronesia dannkepulauan di tengah Samudra Pasifik), jauh kemungkinan dipenganuhi oleh tradisi dari wilayah lain melainkan pengembangan bari pada sub-sistem sosio-idioteknik yang disebabkan perubahan yang terjadi lebih dulu pada subsistem lain, subsistem teknomik selanjutnya mempengaruhi struktur sosial.

Jawaban yang paling bersahaja sebagaimana kesahajaan Urang Kanekes adalah bahwa di budaya Tatar Sunda pada puncaknya merupakan hasil pengembangan insitu tampa pengaruh atau perpindahan dari luar. Sebagaimana dibuktikan dari warisan budaya Klasik (masa Jindu-Budha) terdiri dari sejumlah besar corak tradisi megalitik yang telah dibuat sebelumnya. Bangunan suci yang disebut Kabuyutan telah ada sejak Prasejarah atau akhir masa Prasejarah dan bagi Urang Sunda bangunan-bangunan teras berundak yang telah ada itu dipahami sebagai "tanda" petunjuk dan arah yang diwariskan leluhur karenanya tetap dihormati dan dilestarikan melalui konsep kearifan Sunda Wiwitan. Melalui pola penyaluran bahan dan informasi diantara subsistem sama sebagai perubahan morphostatic (kwantitatif) dan bukan kwalitatif (morphogenetic).

Merubah kondisi alam, mengeksploitasi sumberdaya alam adalah sesuatu yang 
dilarang keras $($ buyut $=$ tabu $=$ pamali $)$ karena hukumnya sama dengan merusak atau merubah yang telah diberikan dan diajarkan oleh karuhun (leluhur). Tatanan Hunian maupun tatanan bangunan suci (Kabuyutan) di Tatar Sunda benar-benar menyesuaikan diri kepada kondisi alam dan seluruh kekayaan di dalamnya. Pertanyaannya adalah bagaimana halnya dengan warisan budaya Situs Batujaya dan Situs Cibuaya dengan segala ciri, karakteristik artefak dan perangkat yang ada berupa sejumlah besar bangunan yang dibuat dari tanah liat bakar (bata) dan arca-arca yang menampilkan bentuk-bentuk tertentu? Apakah benar situs-situs tersebut sejalan dengan tradisi dan budaya Urang Sunda? Suatu "Big Question" yang perlu dicermati dengan seksama adalah letak lokasi di tepi pantai (utara) membuka peluang besar hadirnya berbagai unsur luar.

Jikalau Sunda Wiwitan - Kabuyutan merupakan konsep riil keyakinan (religious background) Urang Sunda, besar kemungkinannya dua situs tersebut bukan dibuat oleh pemangku budaya Sunda, melainkan orang-orang luar yang - bertandang ke Tatar Sunda sesuai kepentingannya.

Tlas Sinurat ing Bintaro, Oktober Pamungkas 2006 


\section{DAFTAR PUSTAKA}

Dodong Djiwapradja (1991 ), Suatu Tinjauan Terhadap Etika Dan Nilai Budaya Pada Masa Pakuan Pajajaran, Proceeding Seminar Nasional Sastra Dan Sejarah Pakuan Pajajaran, Bogor, 11-13 Nopember 1991.

M.M.Soekarto K.Atmodjo, Pengertian Local Genius dan Relevansinya dalam Modernisasi, dalam Ayatrohaedi (peny.,), Keptibadian Budaya Bangsa (Local Genius). Jakarta: Pustaka Jaya. 1986: 46-71.

W.F.Stutterheim (1925), Die Rama-legenden und Rama-reliefs in· Indonesien (The Rama legends and Rama-reliefs in Indonesia), Munchen ; De Stichter der Prambanan-tempels (The Builder of the Prambanan- temples) in Djawa, 1940:218-233.

I G.N. Anom (1996), Keterpaduan Aspek Teknis Dan Aspek Keagamaan Dalam Pendirian Candi Periode (Studi Kasus Candi Utama Sewu). Disertasi. Yogyakarta: Universitas Gadjah Mada.

Franz Magnis-Suseno (1983), Etika Jawa (Sebuah Analisa Falsafi Tentang Kebijaksanaan Hidup Jawa), Jakarta, PT.Gramedia; Noerhadi Magetsari (1986), Locnl Genius dalam Kehidupan Beragama. dalam Ayatrohaedi (penyunting). Kepribadian Budaya Bangsa (Local Genius). Jakarta: Pustaka Jaya. Halaman 72- 79;

Edi Sedyawati (1987), Tarumanagara: Penafsiran Budaya. Diskusi Panel Menggali Kembali Sejarah Tarumanagara. Jakarta, 12 September 1987. Cetakan lepas.

Ronny Siswandi (1986), Pendekalan Emik dan Etik dalam Etnoarkeologi. makalah dalam Pertemuan Ilmiah Arkeologi (PIA) IV, Cipanas, 3-9 Maret. Sub Terna Ill: Konsepsi dan Metodologi. Departernen Pendidikan dan Kebudayaan, Pusat Penelitian Arkeologi Nasional.Halaman 249-263.

Koentjaraningrat (1986), Peranan Local Genius dalam Akulturasi. dalam Ayatrohaedi (peny.) Kepribadian Budaya Rangsa (Local Genius), Pustaka Jaya. Halaman 80-90.

Soerjanto Poespowardojo (1989), Strategi Kebudayaan, Suatu Pendekatan Filosofis. Diterbitkan bekerja-sama dengan LPSP (Lembaga Pengkajian Strategi dan Pembangunan), Jakarta, PT Gramedia

Tanudirjo, D. A. (1994). Epigrafi Indonesia Dalam Kerangka Pikir Pasca - Modernisme. Berkala Arkeologi, 14(2), 10-16. https://doi.org/10.30883/jba.v14i2.634

Drs. Suhendra Yusuf M.A. (1988), Fonetik dan Fonologi. Penerbit PT Gramedia Pustaka Utama, Jakarta.

Moendardjito (1993), Pertimbangan Ekologi Dalam Penempatan Situs Masa Hindu-Buda Di Daerah Yogyakarta, Kajian Arkeologi-Ruang Skala Makro. Disertasi (Program Pasca Sarjana $\mathrm{Ul)}$

Nurhadi Magetsari (1980), Kemungkinan Agama Sebagai Alat Pendekat Dalam Penelitian Arkeologi, makalah dalam Pertemuan Ilmiah Arkeologi (PlA), Cibulan, 21-25 Februari 1977. Jakarta: Pusat Penelitian Purbakala dan Peninggalan Nasional. Halaman 498 - 504. 